Digitized by the Internet Archive in 2016 


\section{COOKING LAKE-BLACKFOOT GRAZING, WILDLIFE AND PROVINCIAL RECREATION AREA}

\section{MANAGEMENT PLAN}

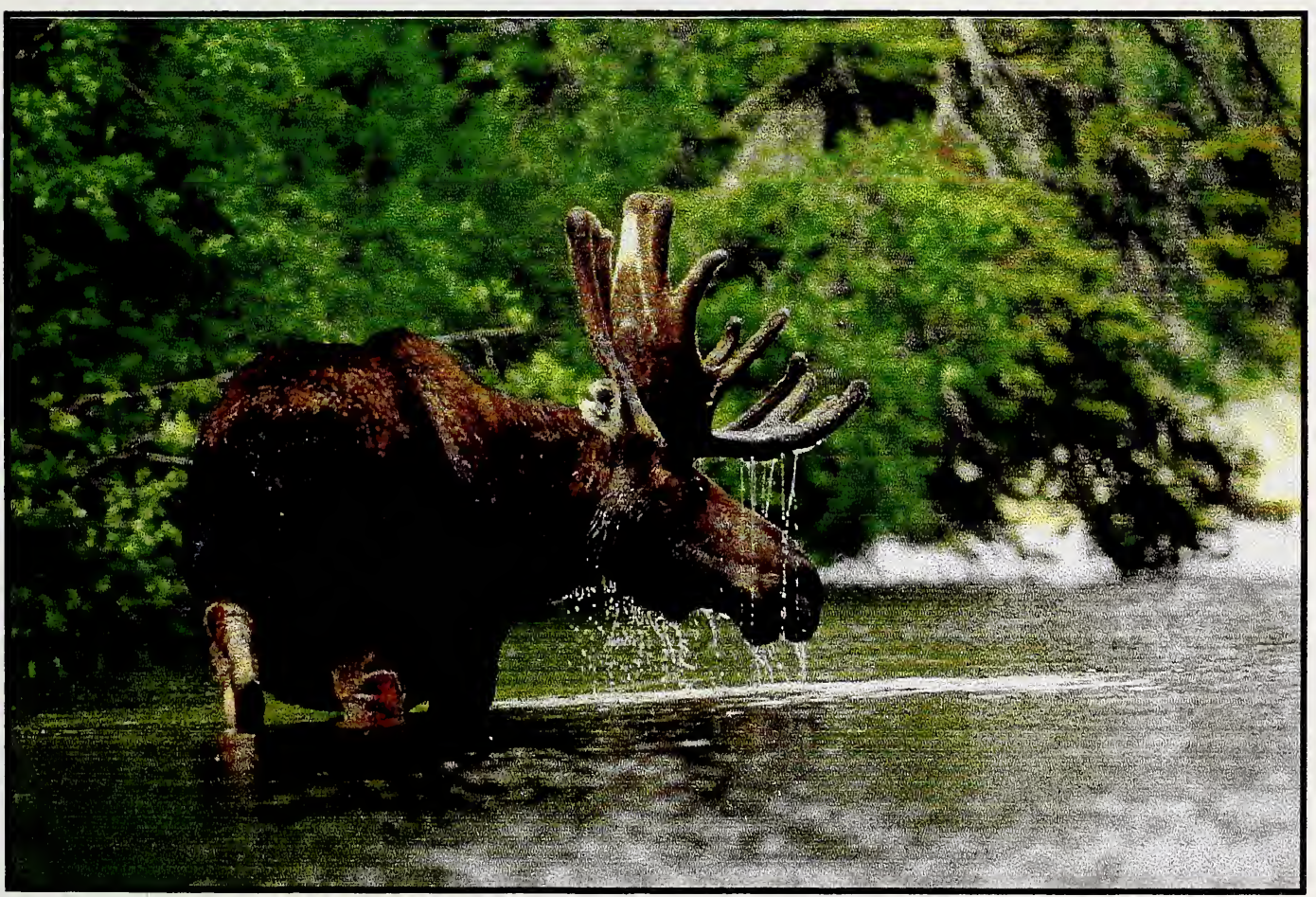


Copies of this plan may be obtained from:

Ranger-in-Charge

Blackfoot Provincial Recreation Area

Alberta Environmental Protection

Box 57104, Eastgate P.O.

Sherwood Park, AB.

T8A 5L7

Telephone: 403-922-3293

Fax: 403-922-5554 


\section{Approval Statement}

The Cooking Lake-Blackfoot Grazing, Wildlife and Provincial Recreation Area Management Plan is the official plan of Alberta Environmental Protection. The Plan is consistent with the provisions of the Provincial Parks Act and General Regulations, and with provincial policies, priorities and direction. The Management Plan updates and replaces both the Blackfoot Grazing Reserve Integrated Resource Plan (1980) and the Blackfoot Operational Plan (1983).

Assistant Deputy Minister, Natural Resources Service

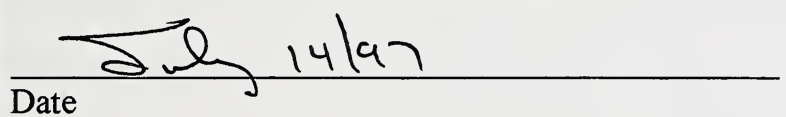

The Blackfoot Management Plan is a commitment by the Region to the protection and management of resources, the provision of recreation opportunities, the delivery of programs and services, and the development, operation, and maintenance of facilities for the Recreation Area.

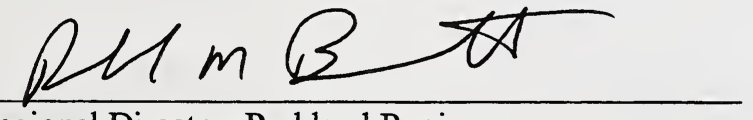

Regional Director, Parkland Region

\section{Tore 1997}

Date 


\section{Recommendation Statement}

The Cooking Lake-Blackfoot Grazing, Wildlife and Provincial Recreation Area Management Plan is recommended for approval and implementation.

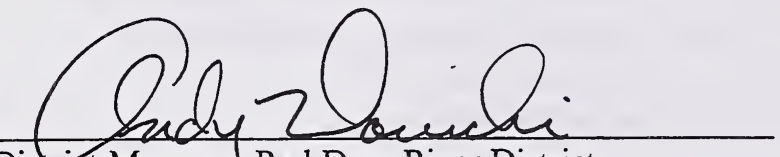

District Manager, Red Deer River District
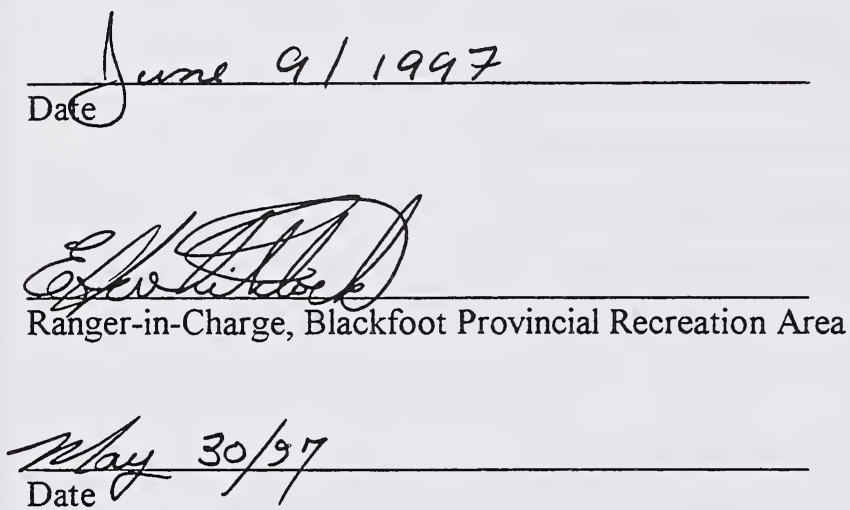

\section{Acknowledgements}

The team responsible for the preparation of the Management Plan included Derry Armstrong, Bill

Diepeveen, Cathy Sveen and Ed Whitelock. The contribution of the members of the public and government staff that played a role in the CORE Table process is also gratefully acknowledged. 
CORE Table Endorsement

We the undersigned represent the Blackfoot CORE Table, comprised of user groups of the Cooking Lake- Blackfoot Recreation Area. The CORE Table was convened to help develop a new management plan for the area. After twenty months of work, we have reached consensus on the attached management plan which we now submit for approval and implementation.

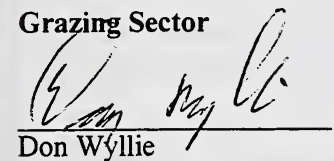

Blackfoot Grazing Association

Hunting Sector

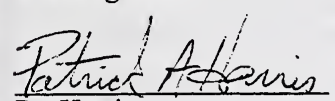

Pat Harris

Sherwood Park Fish and Game

Environmental Sector

Irma Ko claude

Irma Rowlands

Canadian Parks and Wilderness Society

Alberta Wilderness Association

Federation of Alberta Naturalists

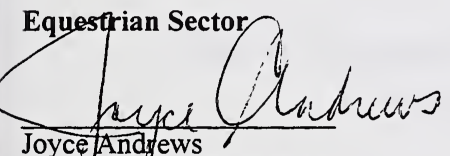

Joyce Andrews

Local Equestrian Riders

Winter Trail Use Sector

Qrumelhe

Doug Keller

Canadian Birkebeiner Society

Summer Trail Sector

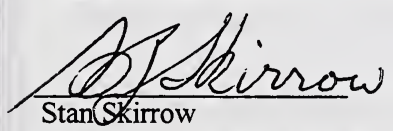

Waskahegan Trail Association

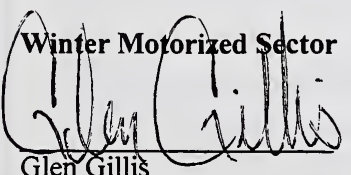

Alberta Snowmobile Association

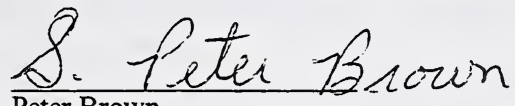

Peter Brown

Blackfoot Grazing Association
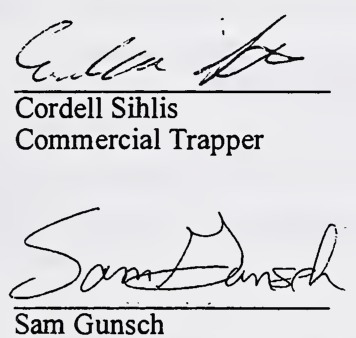

Canadian Parks and Wilderness Society Alberta Wilderness Association Federation of Alberta Naturalists

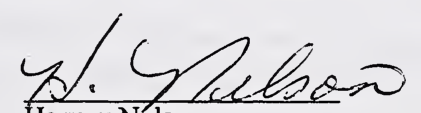

Harvey Nelson Alberta Trail Riders Association

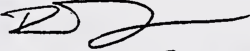

Brenda Friedenberg (Pony Club)

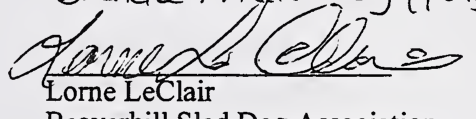

Beaverhill Sled Dog Association

Cathy Scheinew Canadian Birkebeiner Society

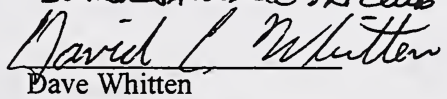

Trail Rider Access Club

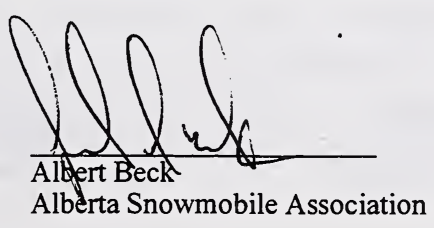

5 
CORE Table Endorsement

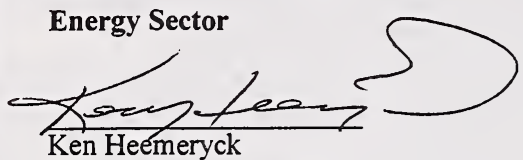

Pinnacle Resources Ltd.

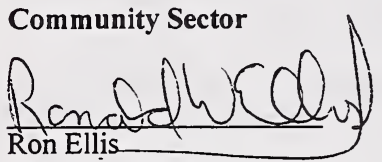

Islet Lake Community

Outdoor/Environmental Education Sector

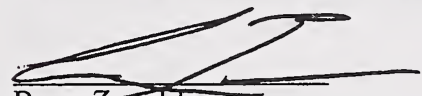

Bruce Zawalsky

Adventure Centre Wilderness Institute

Historical Sector

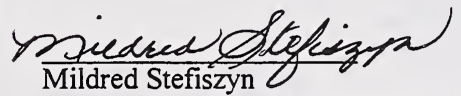

Cooking Lake-Deville Historical Society

Municipal Government Sector

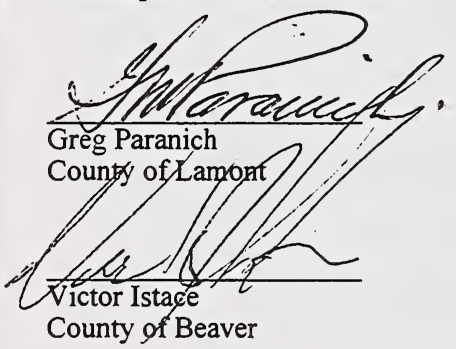

Federal Government Sector

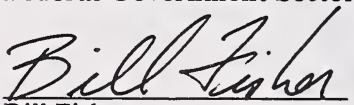

Bill Fisher

Elk Island National Park

Provincial Government Sector

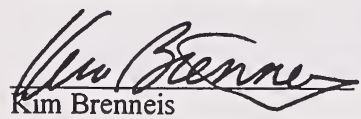

Alberta Environmental Protection
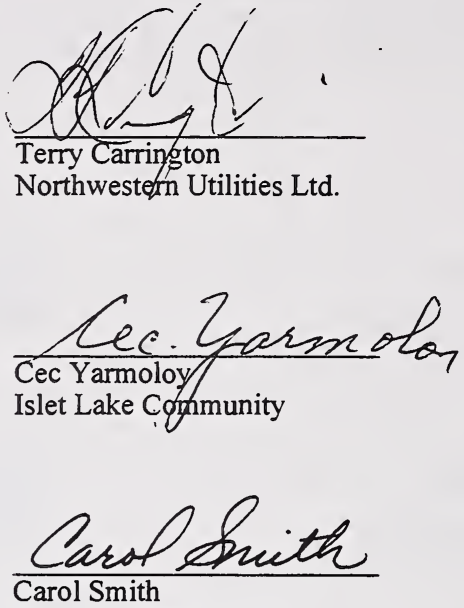

County of Strathcona

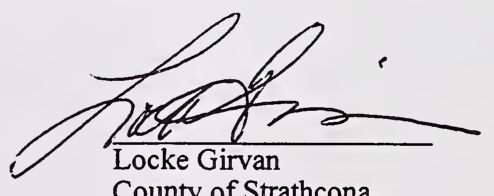

County of Strathcona
Warn Hull

Wayne Holland

Alberta Agriculture, Food and Rural Development

6 


\section{Blackfoot Provincial Recreation Area \\ Management Plan Summary}

\section{Purpose of Management Plan}

The Management Plan provides overall direction for the development, operation, protection and maintenance of the Blackfoot Provincial Recreation Area.

\section{Public Involvement}

The Blackfoot Management Plan was prepared with extensive public participation, focusing on a committee of representatives from community groups and stakeholders. Common areas of concern included: conflicts among various trail activities, the need to expand heritage appreciation opportunities, the impact of hunting on other recreation/resource activities, management of wildlife populations, protection of sensitive plant species, flooding of facilities and adjacent lands, protection of wetlands, and integration of energy industry developments. All of the public concerns were considered as the Plan was prepared.

\section{Vision Statement and Objectives}

The Vision Statement will guide future management of the Recreation Area:

\section{Blackfoot Provincial Recreation Area is a multi-use area that balances existing human activities with the natural area's well being.}

Specific objectives outline the management intent for the Blackfoot:

\section{Outdoor Recreation Objectives \\ Heritage Appreciation Objectives \\ Preservation Objectives \\ Tourism and Economic Development Objectives.}

\section{Management Guidelines}

The Guidelines provide specific management direction for:

Recreation Management- will provide access to trails for activities that are compatible with each other, and focus on the natural attributes of the landscape. The existing trail system will be maintained with only minor extensions including: a new equestrian loop trail to Waskahegan Staging Area, a mountain bike connection to Blackfoot Staging Area, a dog sled perimeter route 
along the south east fence line, groomed snowmobile trails in selected Fields, sharing of equestrian trails with cross country skiers along the Birkebeiner route for the entire ski season, allowance for connections of Blackfoot trails to other regional trails.

Heritage Appreciation- will present information on the natural and cultural themes of the region. Expanded services and an interpretive centre will be investigated, through partnerships and regional coordination.

Wildlife Management- ensure long term protection of wildlife populations and habitat, to promote wildlife viewing, and to integrate hunting and trapping activities with other recreation and resource users.

Vegetation and Grazing Management-managed to maintain a diverse pattern of vegetation types, and protect sensitive plant species. Forage resources will be managed on a long term, sustained yield basis. Other resource and recreation activities may be integrated within pasture areas.

Water and Wetland Management- emphasis on protection of water quality and maintaining diverse wildlife habitat and plant species, while accommodating resource and recreation activities. Access to water for livestock will also be a requirement.

Integration of Energy Industry- New energy developments and existing operations will be managed to minimize impacts on natural resources. Energy activities will be integrated with other resource and recreation uses to minimize potential conflicts.

Special Events- Events that focus on the natural attributes of the Blackfoot will be permitted if they do not restrict other recreation opportunities, or impede resource activities.

Commercial Activities- Services like food concessions or equipment rentals will not be considered. Commercial touring or instruction of outdoor activities may be permitted.

Regional Integration- Blackfoot will work with its neighbours to advance the vision and objectives of the Recreation Area.

Recreation Area Expansion- Land expansion is not a priority. Acquisition of specific lands adjacent to the Area will be considered.

\section{Plan Implementation}

Implementation will be the primary responsibility of Alberta Environmental Protection- Natural Resources Service. Cooperation with partners and stakeholders will be important. Formation of a Cooperating Association and a Government Liaison Group will be pursued to assist with implementation. 


\section{TABLE OF CONTENTS}

APPROVAL STATEMENT

RECOMMENDATION STATEMENT

ACKNOWLEDGEMENTS

CORE TABLE ENDORSEMENT

MANAGEMENT PLAN SUMMARY

TABLE OF CONTENTS

1.0 PURPOSE OF THE MANAGEMENT PLAN

1.1 Public Involvement

2.0 RECREATION AREA OVERVIEW

2.1 Regional Setting

2.2 Present Land Use

2.3 Resource Description

2.4 Cultural History

2.5 Visitor Analysis

3.0 LEGISLATIVE AND POLICY CONTEXT

4.0 BLACKFOOT VISION AND OBJECTIVES

4.1 Vision Statement

4.2 Objectives

5.0 MANAGEMENT GUIDELINES

5.1 Recreation Management

5.2 Heritage Appreciation

5.3 Wildlife Management

5.4 Vegetation and Grazing Management .....................

5.5 Water and Wetlands Management

5.6 Integration of Energy Industry

5.7 Special Events

5.8 Commercial Activities

36

5.9 Regional Integration

5.10 Recreation Area Expansion

6.0 PLAN IMPLEMENTATION

6.1 Plan Monitoring and Review

Appendix I: Vegetation Rehabilitation Seed Mixes 



\subsection{PURPOSE OF THE MANAGEMENT PLAN}

Management plans provide overall direction for the development, operation, protection and maintenance of a recreation area or park. A plan combines the general recreation and resource protection mandate of Environmental Protection, and input from members of the public, into specific direction that can be implemented for each recreation area or park.

The Cooking Lake-Blackfoot Grazing, Wildlife and Recreation Area (Blackfoot Recreation Area) has been operated by Alberta Environmental Protection (formerly the Alberta Parks Service) since the development of the area was completed in 1988. As recreational use of the site has increased, integration with grazing, wildlife management and energy developments has become increasingly difficult.

The original Blackfoot Operational Development Plan (1983) provides some management direction, but many of the current management issues were not anticipated. The purpose of preparing an updated management plan is to review, clarify and elaborate on the original Blackfoot Operational Development Plan. The updated management plan will provide more detailed direction to site managers, to ensure integration of recreation and resource activities, while protecting the natural and cultural values of the area.

The management plan for the Blackfoot Recreation Area will:

- establish the role Blackfoot plays in Alberta's system of parks, recreation areas and protected lands,

- outline a desired vision for the future of the Area,

- define specific outdoor recreation, heritage appreciation, preservation, tourism and economic development objectives for the Area,

- define management guidelines and actions that will achieve the stated vision and objectives

- address existing management issues and concerns identified by the public, through management intent statements, guidelines and action requirements,

\subsection{Public Involvement}

The Blackfoot Recreation Area Management Plan has been prepared with extensive public participation. Brochure/surveys were initially used to identify concerns or issues related to existing management practices. A committee with representatives from a cross section of community groups and stakeholders (referred to as the CORE Table) identified management 
issues and recommendations on how to resolve the concerns. A series of public Open House meetings identified issues, and requested feedback on proposed solutions. Plan Update Newsletters were sent to people that expressed an interest in the planning process.

All of the concerns, comments, ideas and suggestions of the public have been considered as the management plan was prepared. (Details of the public involvement process are available at the Blackfoot Recreation Area Office.)
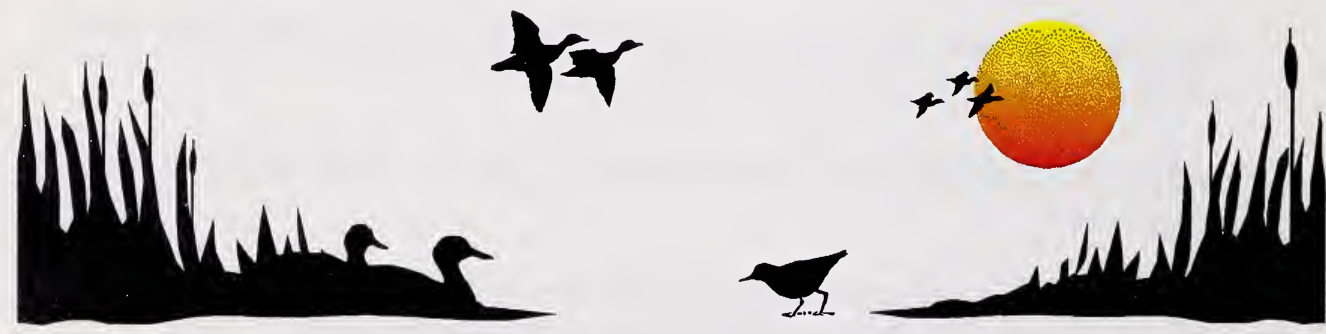


\subsection{RECREATION AREA OVERVIEW}

\subsection{Regional Setting}

The Blackfoot Recreation Area is located approximately $40 \mathrm{~km}$ east of the City of Edmonton in the County of Beaver (No. 9). Total size of the Area is $97 \mathrm{sq.} \mathrm{km}$. (See Map 1). The Blackfoot is located close to several other recreation, protected or cultural areas including Elk Island National Park, Strathcona Wilderness Centre, North Cooking Lake Natural Area, and the Ukrainian Cultural Heritage Village.

Primary access to the Blackfoot is from Highway \# 16, north of the Area, or from the Wye Road to the south. County roads connect four separate staging areas to the highway system.

\subsection{Present Land Use}

The Blackfoot was designated as a Provincial Recreation Area in 1988, and is managed today by Alberta Environmental Protection. The Recreation Area supports a variety of recreational and resource activities that are managed in an integrated, multi-use fashion.

Recreational facilities include four staging areas (Waskehegan, Central, Islet and Blackfoot Staging Areas) that provide parking and picnicking facilities and act as the primary access locations to a large trail system. There are over $170 \mathrm{kms}$ of maintained trails in the Blackfoot providing opportunities for walking, hiking, cycling, equestrian riding, cross-country skiing, snowmobiling and dog sledding. Sport hunting is a popular activity in the autumn, with Aboriginal hunting occurring through-out the year.

Within the Blackfoot Recreation Area, seven field areas totalling 2875 hectares have been cleared, fenced, and seeded to grass and legumes to provide grazing for cattle. The Blackfoot Grazing Association operates the grazing system under a disposition from Alberta Environmental Protection.

A total of 22 natural gas wells have been drilled within the Recreation Area. Twelve of the wells existed when the Recreation Area was designated, and 12 new wells have been drilled since 1988. Pipelines, access roads and a compressor station associated with energy developments are found within the Blackfoot. Pinnacle Resources Ltd. and Northwestern Utilities Ltd. are the primary energy companies that hold sub-surface mineral leases within the Area.

Commercial trapping for furbearing animals also occurs within the Blackfoot. 


\subsection{Resource Description}

Blackfoot Recreation Area is found in an area of highly variable topography, with continuous rolling hills interspersed with numerous ponds, sloughs, bogs and small lakes. The area is part of a larger geological feature known as the Beaverhills-Cooking Lake Moraine.

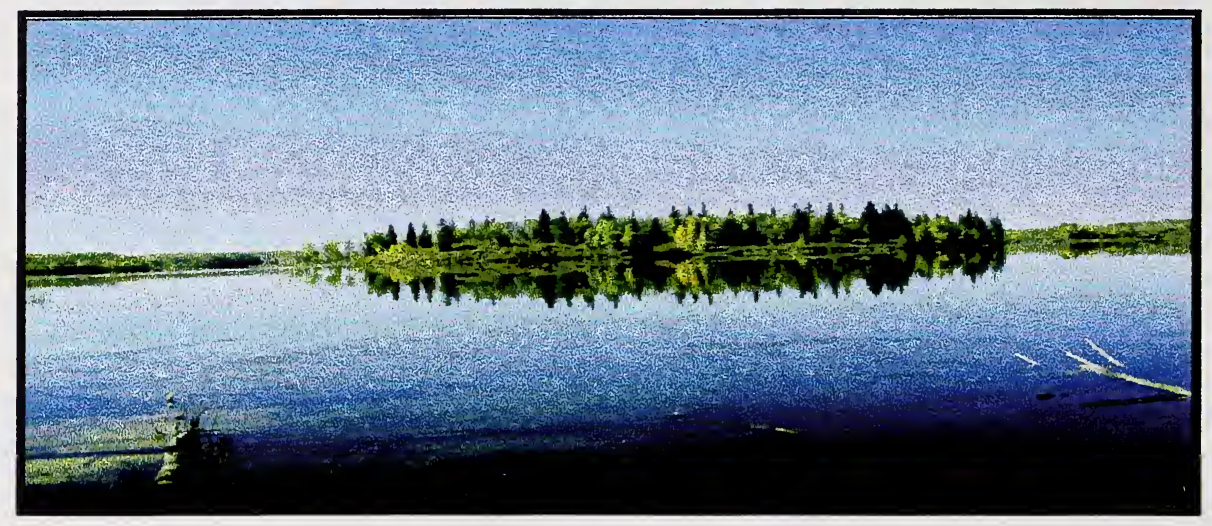

Islet Lake

Major water bodies within the Blackfoot include Blackfoot Lake, Islet Lake, and Elk Push Lake. The Recreation Area also includes the north eastern shore of Wanisan Lake.

Approximately one third of the Blackfoot has been cleared of trees and developed into pasture. The remaining two thirds remains in relatively natural condition. The major forest cover, in well drained areas, is aspen and balsam poplar. White spruce occupies the more irregularly drained areas. The wetness of the area results in a diverse vegetation mix including willow swamps, and bog areas of black spruce, larch and Alaska birch.

The diversity of habitats found within the Recreation Area are suitable for a variety of ungulate species including elk, moose, white-tailed and mule deer. A 2.1 metre fence surrounds most of the Blackfoot to contain ungulate populations. The furbearing animal population includes beaver, muskrats, mink, weasel, foxes and coyotes. Bird inventories indicate that up to 211 species can be found within the Area. Great Blue Herons have nested in a colony located on Blackfoot Lake.

\subsection{Cultural History}

Numerous Indian bands originally hunted in the game rich Beaverhills where the Blackfoot Recreation Area is now found. At Beaverhill and Cooking Lakes, Aboriginal people established permanent camps that acted as base camps for hunting, gathering and fishing. 


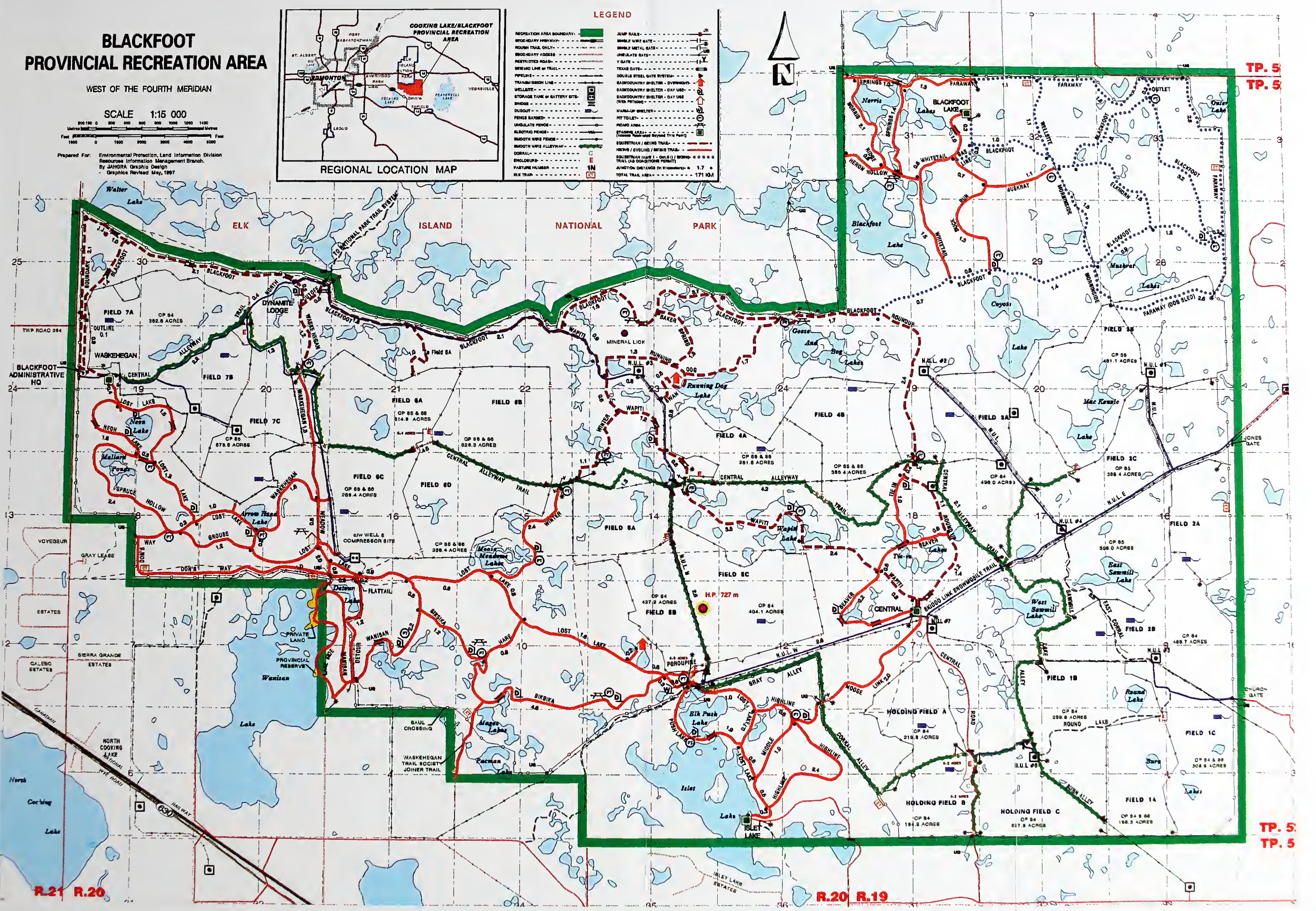





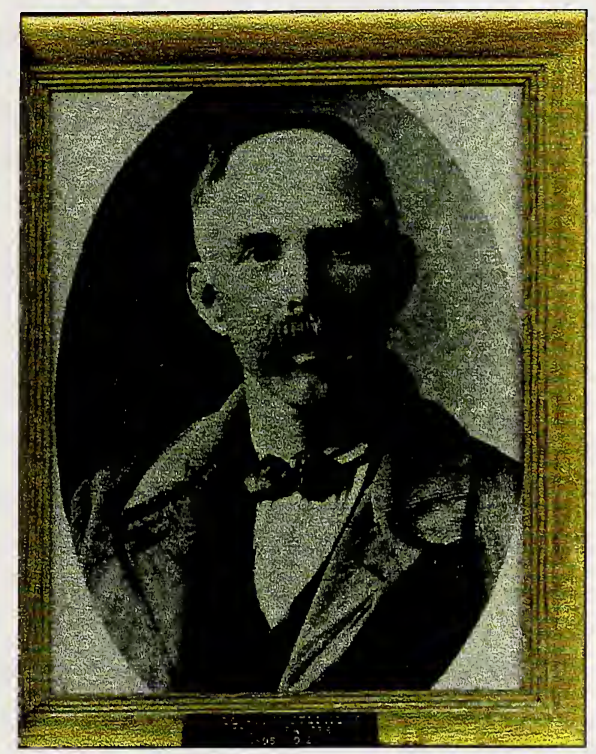

In the 1880's, the Area was part of the Beaverhills Timber Reserve established by the Dominion Government to supply timber for fuel and construction materials for settlement in the region. In 1895, fires lit by homesteaders blew out of control on several occasions, damaging the already poor soils and largely destroying the coniferous forest. In 1899 , the Beaverhills Timber Reserve was reduced in size and renamed the Cooking Lake Forest Reserve. In 1931, the Reserve was turned over to the Province of Alberta. Grazing started in the area as early as 1920 , with the Blackfoot Grazing Association being formed in 1948.

\section{William H. Stephens \\ Forest Ranger \\ 1895-1912}

\subsection{Visitor Analysis}

An estimated 71400 visitors visited the Blackfoot Recreation Area in 1994/95. Use levels have steadily increased since 1991 and continue to grow. Waskehegan Staging Area, at the west end of the Recreation Area, has consistently attracted about $70 \%$ of the total number of visitors. Central, Islet and Blackfoot Staging Areas have split the remaining 30\%.

The most popular summer season activities are hiking/walking, equestrian riding, picnicking and cycling (1992 statistics). Significant levels of hiking, picnicking, and cycling occur in the autumn season. Winter activities focus on cross-country skiing. The Blackfoot is the site of the Canadian Birkebeiner Ski Festival that attracts thousands of skiers to the area each year.

The City of Edmonton is the primary source of recreational visitors to the Blackfoot. Visitors from local communities like Sherwood Park, Ardrossan and Tofield are also common. 


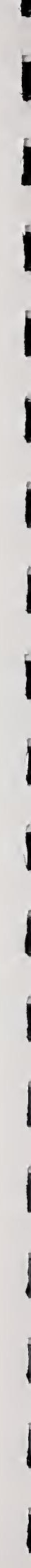




\subsection{LEGISLATIVE AND POLICY CONTEXT}

The following section outlines the overall provincial framework that directs the management of the Blackfoot Provincial Recreation Area.

A 1980 Integrated Resource Plan for the Area stated that the intent of management of the Blackfoot was to maximize grazing through more intensive pasture management, to protect wildlife populations, and to provide opportunities for a variety of outdoor educational and recreational pursuits (Integrated Resource Plan: Blackfoot Grazing Reserve, 1980).

An Operational Development Plan completed in 1983, provided direction for the development of the pastures for grazing, an ungulate fence surrounding the area, as well as the location and standards for recreational staging areas and trails. (Integrated Resource Plan: Blackfoot Operational Development, 1983).

In 1988, the area was formally designated as a Provincial Recreation Area under the Provincial Parks Act, and as such must be managed in accordance with existing provincial legislation and policy direction. Designation under the Parks Act provided the regulations necessary to manage and control the various land uses and activities found within the area. The Provincial Parks Act states that "Recreation Areas shall be developed and maintained to facilitate their use and enjoyment for outdoor recreation". (Section 4, Provincial Parks Act R.S.A., 1988.)

The Blackfoot is part of a Province wide system of recreation and protected areas within Alberta. Alberta's system of recreation and protected areas includes a spectrum of categories that range from highly protected landscapes such as Wilderness Areas and Ecological Reserves through to Recreation Areas. Unlike most Recreation Areas that are small and intensively developed with recreation facilities, Blackfoot includes significant natural landscapes.

One of the roles of the provincial system is the protection of representative examples of each of the Natural Regions of Alberta, from the Rocky Mountains in the west, to the Grassland Natural Region in the southeast. Portions of the Blackfoot Recreation Area play a role within the provincial system. Undisturbed upland landscapes are representative of the Dry Mixed Wood Boreal Forest Natural Region. The wetland areas contribute towards protecting areas that are representative of the Central Parkland Natural Region. (A detailed description of this Natural Regions framework can be found in the report, Natural Regions, Subregions, and Natural History Themes of Alberta: A Classification for Protected Areas Management, 1994.) 



\subsection{BLACKFOOT VISION AND OBJECTIVES}

Effective management of the Blackfoot must meet the overall direction of Provincial policy and legislation, and meet the needs of the people that utilize and enjoy the area. In order to clarify the intent of future management the Area, a vision statement and specific objectives for outdoor recreation, heritage appreciation, preservation, tourism, and the economic development of Blackfoot Provincial Recreation Area are presented in detail.

\subsection{Vision Statement}

The vision statement will guide the future management of this area and reflect what the public has expressed through their involvement in the management planning process.

\section{Blackfoot Provincial Recreation Area is a multi-use area that balances existing human activities with the natural area's well being.}

\subsection{Objectives}

The Alberta Parks system has adopted four broad program objectives: outdoor recreation, heritage appreciation, resource protection, and tourism/economic development. The broad provincial objectives can be used to provide general direction for management of the overall Provincial Parks System. For each site within the System, a set of more specific and detailed objectives are required to guide local management direction. The following are management objectives for the Blackfoot Provincial Recreation Area.

\section{Outdoor Recreation}

Blackfoot Provincial Recreation Area will:

- support provision of recreation activities that focus on the natural attributes of the area.

- provide day-use recreation opportunities through-out the year.

- maintain a system of trails or areas for walking/hiking, cycling, equestrian riding, snowmobiling, cross-country skiing and dog sledding.

- provide picnicking opportunities at staging areas and backcountry shelters. 
- provide safe opportunities for recreational and Aboriginal subsistence hunting.

- promote increased use of the area for nature appreciation and wildlife viewing.

- integrate the recreational opportunities offered at Blackfoot into the surrounding region.

- minimize conflicts among various recreational users.

\section{Heritage Appreciation}

Blackfoot Provincial Recreation Area will:

- enhance visitor understanding, use, and enjoyment of the natural and cultural resources of the area.

- provide environmental educational opportunities for youth and school groups throughout the year.

- recognize, record, protect, preserve and present the history of the Cooking LakeBlackfoot area in non-intrusive ways.

- work cooperatively with existing heritage groups in the surrounding region.

- provide information on other heritage appreciation opportunities in the region, as well as other sites within the provincial parks system.

\section{Preservation}

Blackfoot Provincial Recreation Area will:

- ensure the long term viability and health of the natural ecosystem.

- protect rare, threatened, and endangered wildlife and vegetation species.

- protect undisturbed portions of the upland landscape as a site representative of the Dry Mixed Wood Boreal Forest Natural Region, and wetlands as representative of the Central Parkland Natural Region.

- maintain sustainable and healthy populations of ungulates and furbearing wildlife species. 


\section{Tourism and Economic Development}

Blackfoot Provincial Recreation Area will:

- provide opportunities for livestock grazing while managing the forage resources on a long term, sustained yield basis.

- integrate resource exploration and development activities.

- minimize conflicts between resource and recreational activities.

- promote the area as an eco-tourism and recreation destination, as part of the surrounding region. Commercial services will not be provided within the Recreation Area.

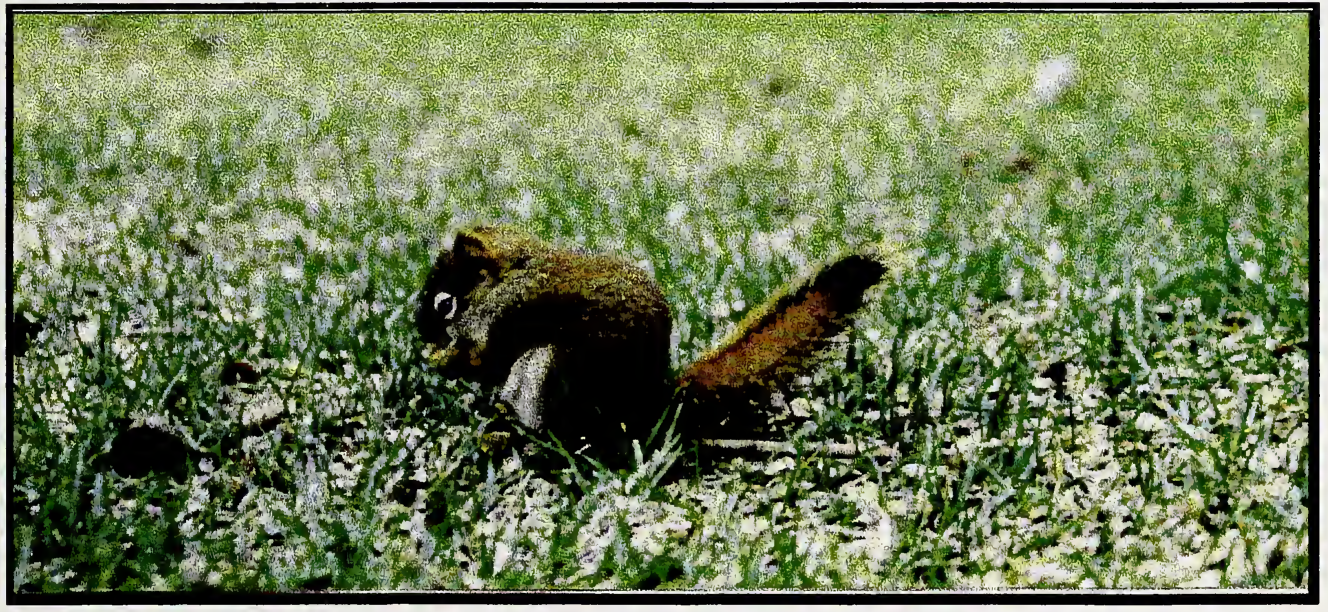

Common Red Squirrel 



\subsection{MANAGEMENT GUIDELINES}

Overall management of the recreational and resource activities within the Blackfoot Recreation Area will be in accordance with the following Guidelines.

\subsection{Recreation Management}

Recreation activities within the Blackfoot will focus on the extensive trail system. The $170 \mathrm{kms}$ of maintained trails accommodate walking, hiking, cycling, equestrian riding, cross country skiing, snowmobiling and dog sledding. Some trail activities, like walking, hiking and cycling, are able to share trails because the activities have been found to be compatible. Other activities are separated and directed to specific trails, due to possible conflicts and safety concerns. Example of activities that are separated include equestrian riding and cycling, or cross country skiing and snowmobiling.

The four Staging Areas within the Recreation Area serve primarily as the access locations for the trail system, providing information, parking and washroom services. The Staging Areas also provide opportunities for picnicking with tables, shelter buildings, drinking water and fire pits.

There are three backcountry shelters located within the Recreation Area. The shelters provide picnic opportunities for visitors using the trail system. Two of the shelters are also made available for overnight use by organized youth and educational groups, as a base for backcountry camping. No other overnight camping is permitted within the Recreation Area.

Issues- Conflicts among various trail users have been a major management issue within the Blackfoot. Expansion of the existing trail system was raised in the public input process, as well as requests to make new trail connections to trails that surround the Blackfoot. Requests for development of campground facilities at Staging Areas and in the backcountry were received. More backcountry and heated winter shelters were also requested.

Management Intent- The primary intent of recreational management within the Blackfoot Recreation Area is to provide access to trails for activities that are compatible with each other and focus on the natural attributes of the landscape. The following are specific management guidelines to direct recreational management.

\subsubsection{Guidelines for Staging Areas}

The four Staging Areas (Waskehegan, Islet, Central, and Blackfoot) will be managed to provide access to the trail system. Parking lots will be maintained and provide adequate room for vehicles with trailers. The parking lot at the Blackfoot Staging Area will be redesigned and expanded to accommodate vehicles pulling horse trailers, as funding becomes available. 
Information, orientation and heritage appreciation services will be provided at all Staging Areas, primarily through the use of signs, maps and brochures.

Picnicking opportunities will be maintained at each Staging Area through the provision of picnic tables and shelters, fire pits, drinking water and washrooms.

No overnight camping facilities or services will be provided.

\subsubsection{Guidelines for Internal Trails}

The existing $170 \mathrm{kms}$ of internal trail system will be maintained (see Map of Winter and Summer Trails). Only minor expansions or extensions to the trail system will be considered. Specific modifications are detailed below.

Trails will generally be shared, except where activities have conflicting trail maintenance standards, or there are safety concerns between uses. Trail etiquette and safety will be a major focus of public information for the Blackfoot, in order to minimize conflicts among trail users.

All trail users will be encouraged to remain on the designated trail system.

New recreational pursuits may be considered for the trail system, if the activity does not conflict with other existing activities, and does not negatively impact the natural environment. The cumulative impact of new trail activities on the environment and other activities within the Blackfoot will also be considered. The addition of new recreational activities will only be approved following public review and comment.

Trails may be temporarily closed during wet periods to avoid damage to trail surfaces. Portions of trails that are frequently damaged by wet conditions will be upgraded, as funding permits.

Trail conditions will be monitored on an ongoing basis, and partnerships with volunteer groups developed to implement upgrading, repairs and maintenance.

Hiking- Hiking and walking will be permitted on all trails during the non-snow season. Hiking with dogs will be discouraged on equestrian trails.

Equestrian- Equestrian use will focus on the trail system north of the Central Alleyway, including the Central Alleyway, the NUL roads, and trails east of the Blackfoot Staging Area. In addition, fields where cattle are not grazing will generally be open for equestrian riding.

The season for equestrian use of trails east of the Blackfoot Staging Area will be closed for November 1 to March 31 each season to accommodate trail grooming for cross-country skate skiing. Special permission may be granted to hunters to use horses during the closed season in order to extract game. Hunters using horses will be required to remain on designated trails. 
Equestrian trails will be available for horse driving, when trails are open for equestrian use.

A new equestrian trail loop to Waskehegan Staging Area will be constructed around the southern perimeter of Field $7 \mathrm{C}$ and $7 \mathrm{~B}$, inside the existing barb wire fence. A second fence of equivalent standard will be constructed 16 feet inside the existing perimeter fence. The new fence will be developed through a partnership of agencies and stakeholder organizations.

In addition, equestrian access across portions of Field 7 will be accommodated when cattle are not present in that portion of the Field. Fencing changes required to accommodate equestrians will be developed through partnerships. New directional and information signs will be installed to identify the equestrian routes available in Field 7. The impact of horse use on the pasture in Field 7 will be monitored to ensure no loss of grazing for cattle. Remedial measures will be

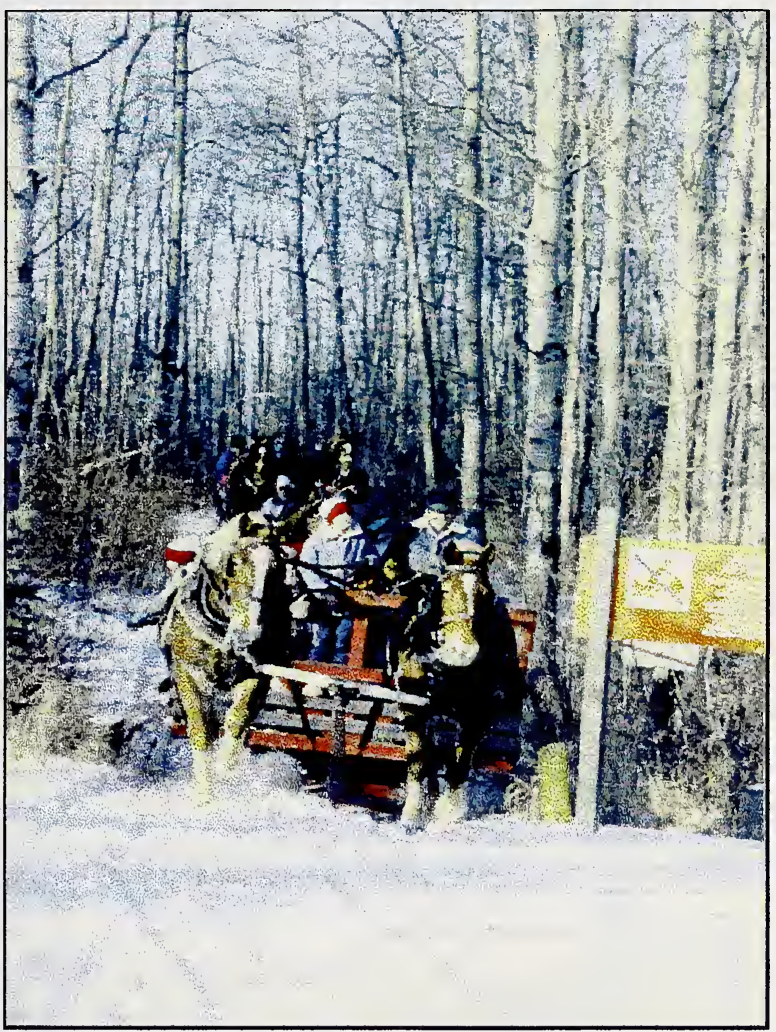

Winter Sleigh Ride - Waskehegan implemented by Environmental Protection, if necessary.

An improved horse trail will be developed along the side of the Central Alleyway to provide a better quality return loop to Waskehegan Staging Area.

Mountain Biking- Mountain bikes will share the hiking trails south of the Central Alleyway, and west of the Blackfoot Staging Area. Mountain bikes will not be permitted on equestrian trails, except for the specific sections that connect from Central Staging Area to the Blackfoot Staging Area, as noted below.

A mountain bike trail connection will be accommodated, for the majority of the summer season, between the Blackfoot Staging Area and Central Staging Area. The route follows the NUL road that crosses through Field $3 \mathrm{~A}$. The trail will be signed as closed to cyclists when cattle are in Field 3A, and the mountain bike connection between the two Staging Areas will not be available via other trails. When Field $3 \mathrm{~A}$ is open to cyclists, a section of Round-up and Blackfoot trails will be shared by equestrians, hikers and cyclists. Special safety and etiquette signs will be installed. 
Dog Sledding- Dog sledding will be permitted on trails located east of the Blackfoot Staging Area that are also used for skate-skiing. Dog sledding will also be allowed on a route from the Blackfoot Staging Area that follows the east and south ungulate fence, and returns through Fields 1,2 , and 3. Dog sledding will not be permitted at Central Staging Area due to conflicts with horses.

A wildlife monitoring program will be set up along the south east perimeter trail to assess the impact of dog sledding on wildlife.

Snowmobiling- Snowmobiling will be allowed along the Central Alleyway from Central to Waskehegan Staging Areas and in selected Fields, when there is sufficient snow cover to minimize damage to vegetation $(25 \mathrm{~cm})$.

Snowmobile trails will be groomed in the Fields open to snowmobiling, in order to provide better quality trails. The impact of trail grooming on the pasture vegetation will be monitored to ensure no negative impacts.

The snowmobile trail connection from Central Staging Area to the Central Alleyway will be widened by removing encroaching vegetation.

Cross Country Skiing- Ski trails will be maintained on trails south of the Central Alleyway and on the trails surrounding the Blackfoot Staging Area.

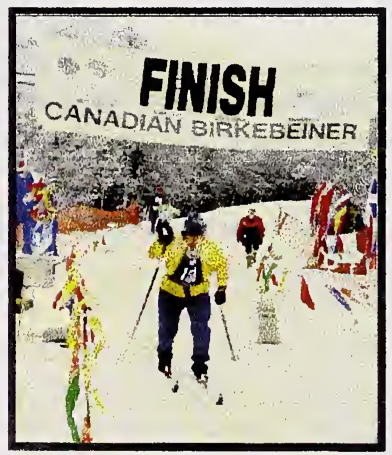

Ski trails will be prepared on portions of the equestrian trails (Round-up, Wapiti, and North Winter) for the Birkebeiner Ski Festival. The trails will be closed to equestrians four weeks prior to the Birkebeiner to allow time to groom the trails for skiing. On a trial basis, the Birkebeiner route (Round-up, Wapiti, and North Winter) will be shared between equestrians and skiers during the entire winter season. Track setting for skiing would be optional on the shared portions of trail. Signs on the shared portion will emphasize skiing-equestrian trail etiquette.

\section{Birkebeiner Ski Festival}

\subsubsection{Guidelines for Connections to External Trails}

A number of trail systems exist or have been proposed on lands surrounding the Blackfoot and there have been requests to connect the adjacent trails into the Blackfoot trail system. 
 \\ TRAIL INFORMATION COOKING LAKE BLACKFOOT RECREATION AREA}

Equestrion Trall

Equestrlan Pormltted
(April 1 to October 31 )

NUL Northwostorn UtIlltios

iili Woshroom

- $\bullet \bullet \bullet$ (April 1 to October 31)

— - HikIng/Cycling Troll

Accoss Road

[ Trellhead

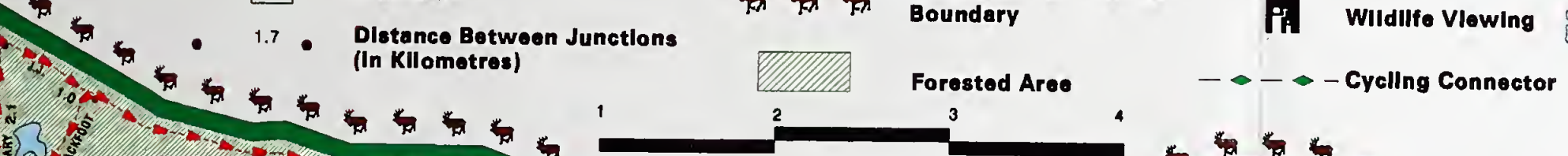

Rocrootlon Area
Boundary

Elk Island Natlonal Park

Boundary
Pif Wildilfo Vlowing

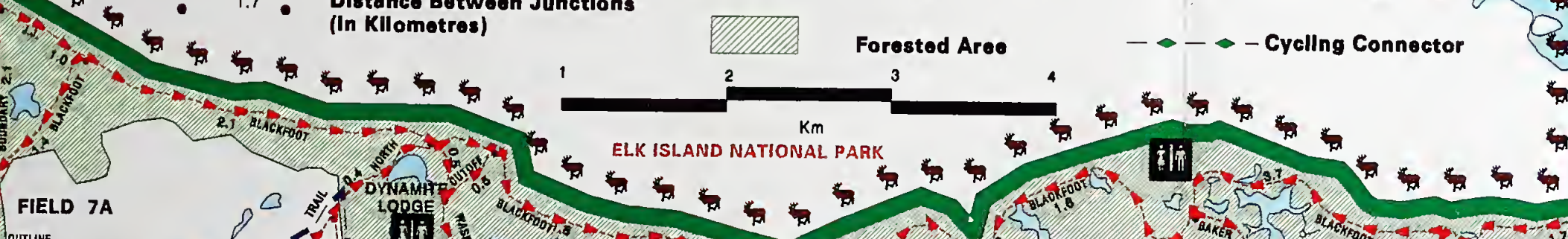
20

$-7.25$

\section{国 国}

FIELD $7 \mathrm{~B}$

if 0.00

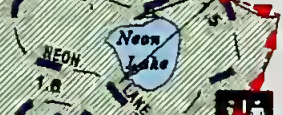

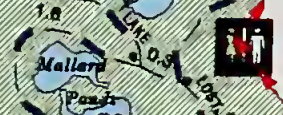

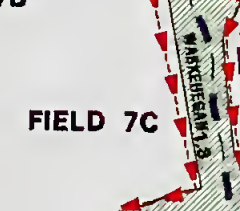

in

$\checkmark$ FIELD 6A

FIELD 6B

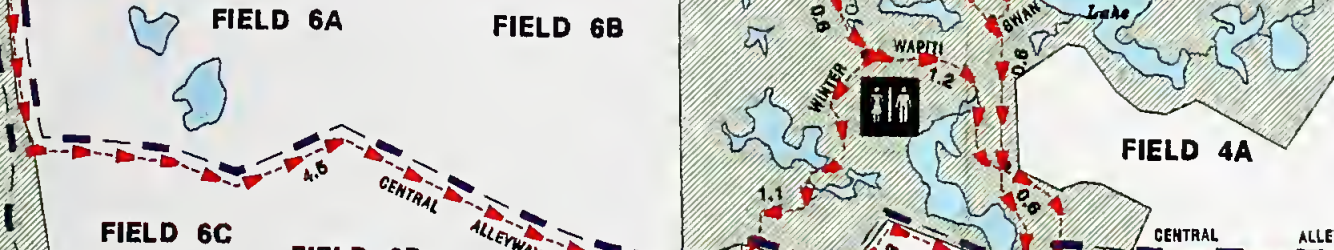

2.

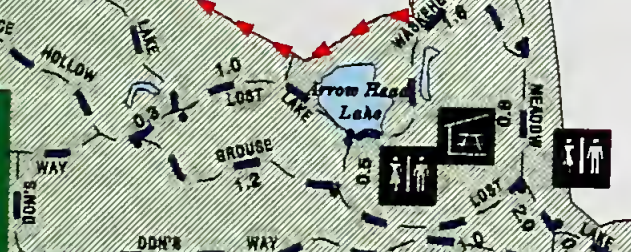

of

-

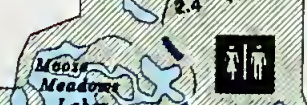

$\overrightarrow{F I E L D ~ 5 A}_{5}$
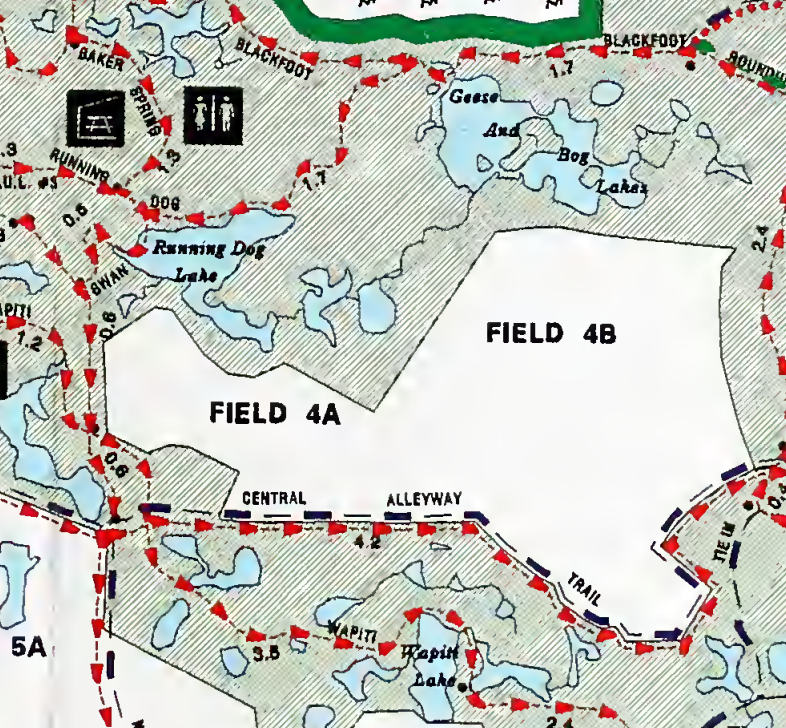

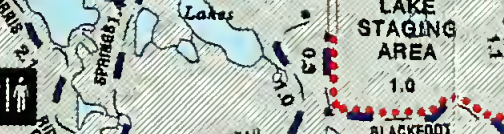

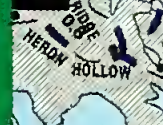

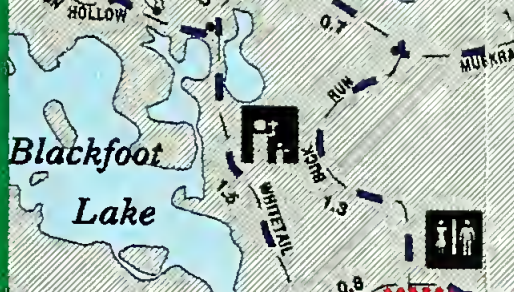

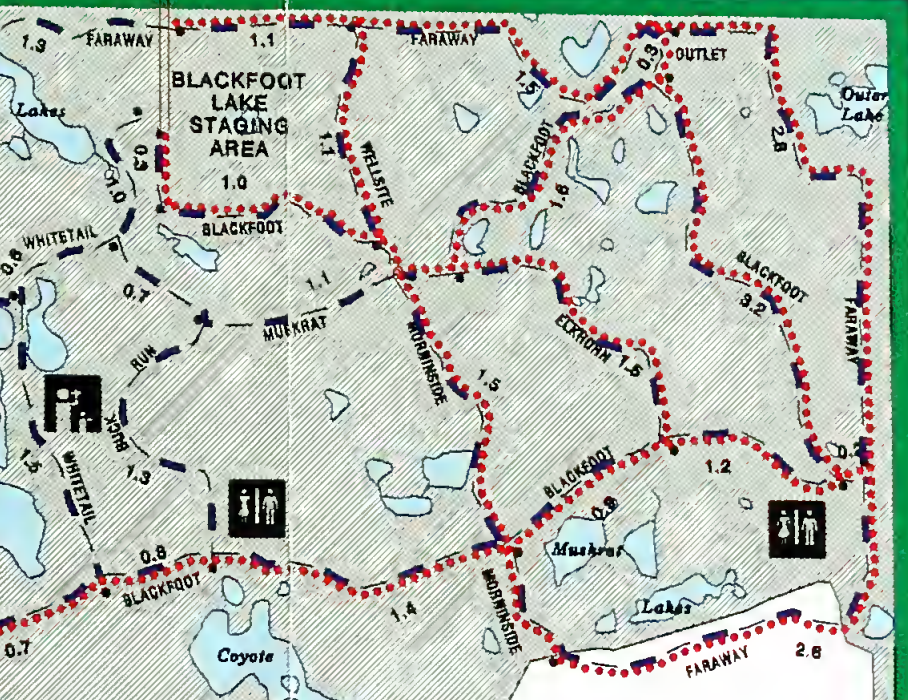

FIELD 3B
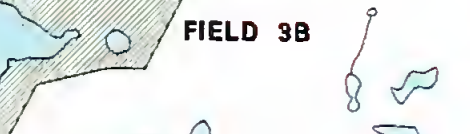

210
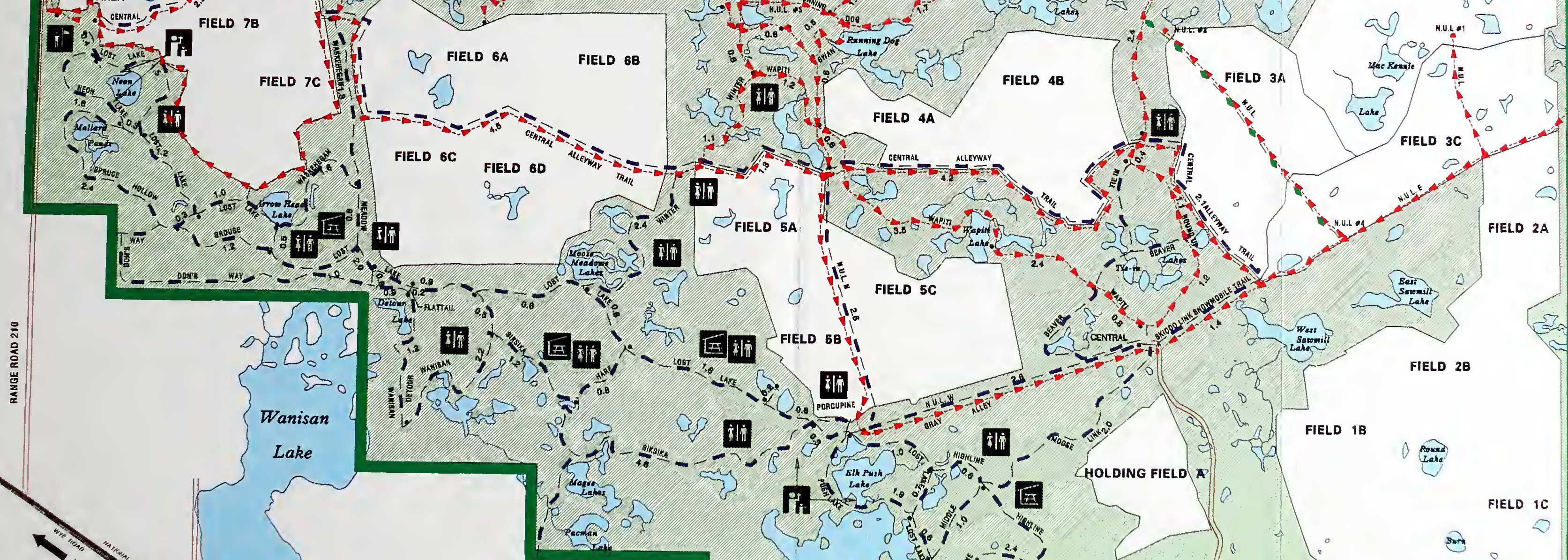

Q.
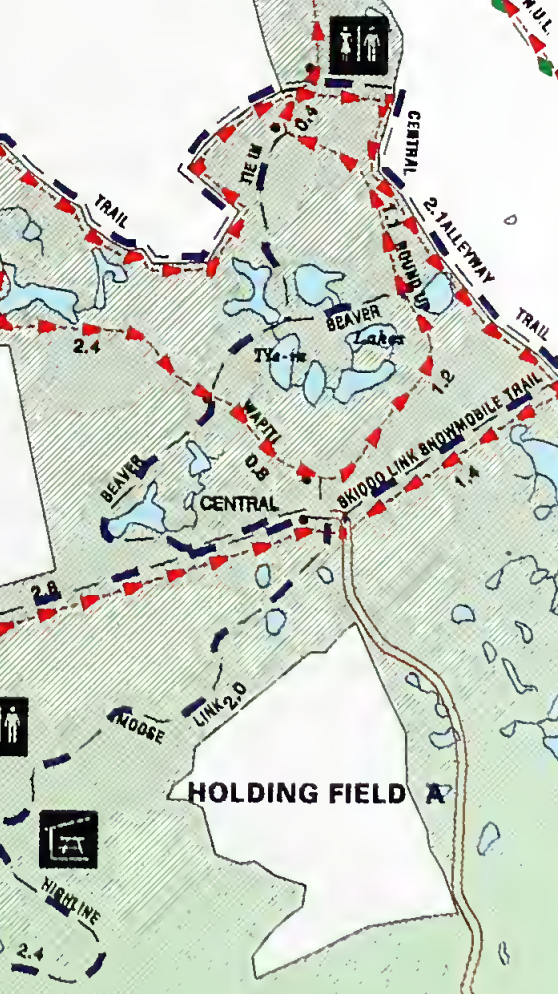

-

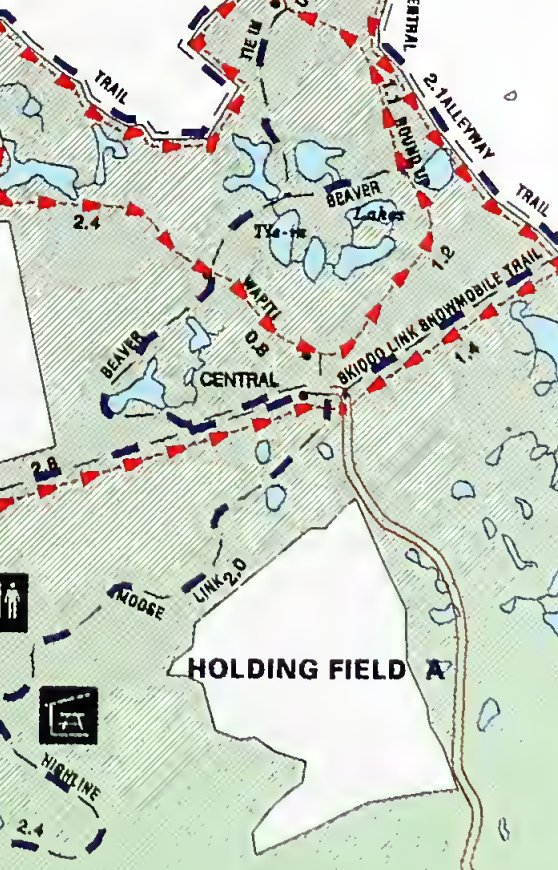

HOLDING FIELD $B$

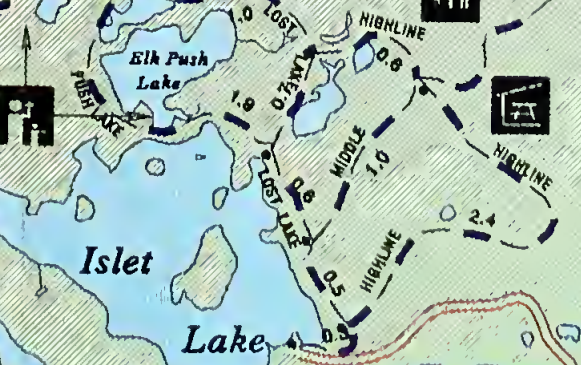

FIELD 18

10 Randed

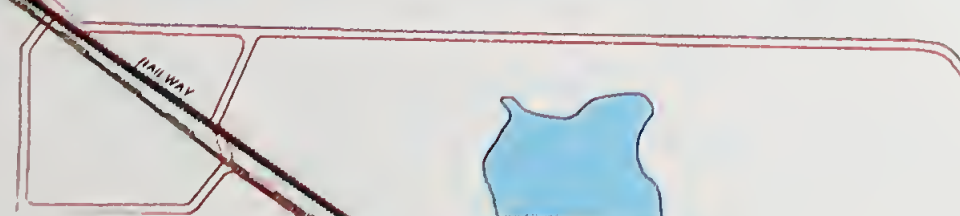




Trail connections into the Blackfoot trail system will be supported if the trail activities are compatible with activities occurring within the Blackfoot. The following connections will be supported:

- a north/south hiking route along the Waskehegan Trail in Blackfoot connecting to the Cooking Lake Trail in Elk Island National Park.

- a linked hiking trail between Elk Island National Park and the Blackfoot in the vicinity of the Heron Hollow Trail.

- connection with the Edmonton Regional trail initiative /Trans-Canada Trail.

- connection with the Strathcona Wilderness Centre trails.

- an outside connection with the Ukrainian Village for the Birkebeiner Ski event.

- an equestrian trail connection outside the ungulate fence, along the south boundary from Islet Lake area to the Central Staging Area access road.

- the snowmobile trail along east ditch of $R R \# 210$ will be re-routed to avoid snowmobiles crossing the road. Tree planting will be required to ensure snowmobiles return to the ditch and do not travel the ungulate fence buffer strip.

The issue of a snowmobile through-route into the Waskehegan Staging Area and along the entrance road into Central Staging Area, and a snowmobile trail along the Blackfoot ungulate fence near Wanisan Lake, will be deferred until the County of Strathcona decides on a regional snowmobile route. Changes in the snowmobile trails within the Blackfoot will be discussed with the public prior to implementation.

\subsubsection{Guidelines for Backcountry Facilities}

Existing facilities along the trail system include toilets, benches, and three picnic shelters.

No additional facilities will be provided in the backcountry. Use of the backcountry picnic shelters will be limited to day-use. Organized youth and educational groups may reserve the Lost Lake and Running Dog shelters for overnight use.

\subsection{Heritage Appreciation}

Heritage appreciation is the presentation of information to visitors to help them explore, understand and appreciate the natural and cultural heritage of the Blackfoot Recreation Area and 
surrounding lands. Heritage appreciation services at Blackfoot currently focus on the settlement and development history of the area, as well as, the natural resources and features of the site. The methods of presenting information will focus on signs and brochures available at the Recreation Area office and the four Staging Areas.

Issues- Issues identified in the management planning process highlighted a need to integrate heritage appreciation at the Blackfoot with other nearby organizations and agencies. The desire for development of a heritage interpretation centre was raised. There were also suggestions on the type of information that could be presented for the Area.

Management Intent- Heritage appreciation services at the Blackfoot will continue to present information on the natural and cultural themes of the region. Expanded heritage appreciation services will be investigated, through the use of partnerships and coordination of regional efforts.

\subsubsection{Guidelines for Heritage Appreciation}

Future heritage appreciation will be directed by the following guidelines.

Themes for presentation may include:

- Natural features that are not sensitive to direct human impact.

- Aboriginal peoples traditional use of the area.

- Overview of the people who came and used the area, such as settlers, historic people, foresters and ranchers.

- Identification and interpretation of archeological sites (aboriginal peoples) and historic settlement sites.

- History of the land use in the areas, such as forestry (e.g. sawmills), grazing, ranching, and oil and gas development, including the ecological influence on settlement and use.

- History of local land conservation.

- The influence of settlement and use on the ecology of the area.

- Recreational uses over time.

- The influence of changes in transportation on the area (e.g. trails, roads, railroad). 
The human history of the area will be presented in a non-judgemental and objective manner, with a regional perspective of the whole Cooking Lake Moraine. The stories presented will highlight the interaction and use of the natural resources by humans through time.

Information on other heritage appreciation opportunities within the region and the Provincial Parks system may also be presented.

On-site presentations will focus on signs and brochures distributed at the Staging Areas.

Environmental education opportunities for youth groups and school groups will be a high priority. Opportunities will be primarily provided through the use of backcountry sites for overnight camps.

Development of an interpretive centre in the Blackfoot Recreation Area will be investigated, through partnerships with other groups, companies, agencies and Indian Bands.

Existing trails and sites that have historical significance will be recognized and highlighted.

Coordination of heritage appreciation themes and services will be initiated with surrounding groups and agencies within the Cooking Lake moraine region.

\subsection{Wildlife Management}

A wide variety of wildlife species inhabit the Blackfoot Recreation Area. The largest mammals include moose, elk, mule and white-tailed deer, and coyote. Smaller mammals include beaver, foxes, muskrat, weasel, skunk and red squirrels. Over 200 bird species have been recorded as residents or visitors to the Area. Birds that are known to nest in the Area include Great Blue Heron and several species of migratory waterfowl. Trumpeter swans (an endangered species) have been observed on several lakes within the Area, and nesting has occurred on Running Dog Lake. The Trumpeter swans seen in the Blackfoot are part of a reintroduction nesting program based in Elk Island National Park. No detailed inventories of amphibian or insect species have been conducted.

Recreational hunting is a major part of wildlife management in the Blackfoot. A $47 \mathrm{~km}$ ungulate fence is maintained around the Blackfoot perimeter to stop ungulates from foraging on surrounding agricultural crops. A limited draw hunting season is scheduled each Fall for elk, and there is a regular hunting season for white- tailed deer. At present, there is no recreational hunting season for moose or mule deer. Seasons are also available for migratory and upland birds. Subsistence hunting by Treaty Indians occurs year-round. A Discharge Permit is required by all hunters, including Treaty Indians, that visit the Blackfoot Recreation Area.

A Registered Fur Management Area for commercial trapping exists within the Blackfoot. 
Trapping of furbearing animals is primarily for beaver and coyote. In addition to commercial trapping, beavers and beaver dams are removed when their activities conflict with facility management efforts.

Viewing of wildlife is a popular activity with visitors. Viewing locations and interpretive signs and materials are made available on the trail system to encourage wildlife viewing.

Issues- The primary management issues relating to wildlife perceived by the public are: concerns about the impact of hunting on other recreation and resource activities, maintenance of the ungulate fence, the availability of discharge permits and access to hunting, and the maintenance of habitat to sustain wildlife populations in the long term.

Management Intent- The intent of management of wildlife in the Blackfoot Recreation Area is to ensure the long term sustainability of populations and habitat, to promote wildlife viewing with visitors, and to integrate hunting and trapping activities with other recreation and resource users. The following are specific guidelines to direct wildlife management.

\subsubsection{Guidelines for Wildlife Management}

Inventory and Monitoring- Wildlife inventories will be conducted for selected indicator species to establish an information base. Monitoring of indicator species will be conducted on a regular cycle. Inventories of the primary hunting and trapping species will be undertaken every 2-3 years. Wildlife inventories and monitoring programs will be integrated with Elk Island National Park, where feasible.

Sensitive wildlife populations and their habitat will be monitored as potential threats are identified. Specific management actions may be implemented to protect the animals or habitat including temporarily redirecting people away from sensitive locations, or even permanently closing areas from public use.

Trapping- A Registered Fur Management Area for commercial trapping will be maintained. Management of furbearer populations will be a joint responsibility of the RFMA holder and Environmental Protection. Trapping will be used as a means of controlling problem furbearers such as coyote and beaver. Trapping will be managed at levels that ensure long term sustainable population levels and a healthy population.

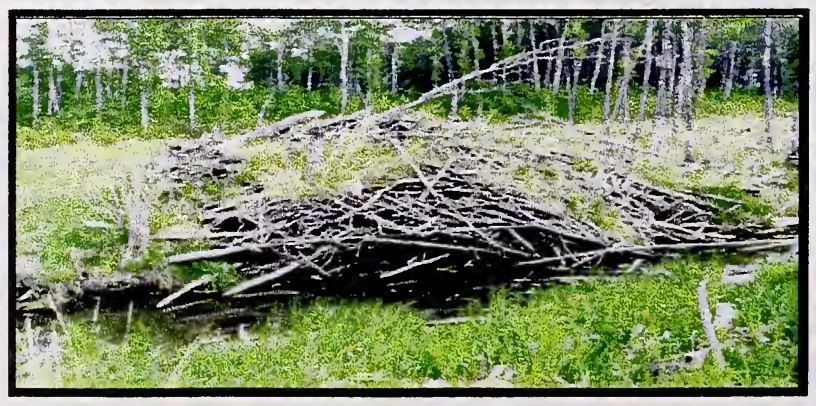

Beaver House 
Control of beavers will continue where their activities result in negative impacts on roads or recreational facilities. A range of management actions will be used including: ongoing winter trapping; installation of wire culvert cages; and reconstruction, relocation, or temporary closure of facilities to accommodate flooding. Removal of beavers and dams may occur when other management actions have failed or are considered impractical.

Hunting- Limited season recreational hunting and year-round Aboriginal hunting will continue to be used to control big game populations. The recreational hunting seasons will occur primarily in the late Fall, in order to minimize conflicts with other recreational activities. The white-tailed deer season and elk season will be adjusted to overlap for two weeks.

No- hunting zones of 400 metres will be maintained around all staging areas and 200 metres around backcountry shelters. The boundaries of the no-hunting zones will be marked "as the crow flies".

Foot travel for hunting will be allowed throughout the Recreation Area. Hunters may also use bicycles, horses and snowmobiles on the designated trail system and fields that are open for recreation.

Discharge permits will be required by all hunters in order to meet the requirements of the Provincial Parks Act, and to provide specific safety information. Information on current energy activities, and general firearms safety and etiquette will be provided to hunters. Information about recreation events will also be provided to hunters. Methods of making Discharge Permits more available to hunters will be investigated. Population goals for the major ungulate species will be:

\section{Species}

Moose

Elk

White-tailed Deer

Mule Deer
Estimated Population (1996)

80

170

300

20
Goal

100

150

200

50

When big game populations are at or above the goal, sport hunting seasons may be used to maintain or reduce the populations to the desired level. If populations drop below the goal, the sport hunting season may be adjusted until populations meet the goal.

Ungulate Fence- the ungulate fence on the perimeter of the Blackfoot will be maintained by Environmental Protection in order to minimize conflicts with surrounding agricultural landowners, and wildlife-vehicle collisions along adjacent roads. Upgrading and maintenance of the fence is required to maintain the function of the structure.

Wildlife Viewing- Opportunities for wildlife viewing will be promoted. Information brochures outlining viewing opportunities will be maintained. Additional wildlife signs and viewing platforms or blinds will be considered where appropriate sites are accessible. 


\subsection{Vegetation and Grazing Management}

The majority of land in the Blackfoot is forested with trembling aspen and balsam poplar in upland areas, and black spruce, larch and Alaska birch in wetter sites. Some of the wettest areas are dominated by willows, aquatic grasses and sedges. Mature white spruce are found in a few isolated locations like the island in Islet Lake.

The diversity of vegetation within the Blackfoot provides excellent habitat for a wide variety of wildlife species.

Grazing of cattle has occurred in the Blackfoot Area since at least the 1920's. As part of the development of the site in the 1980's, the Government of Alberta cleared an area of 2875 hectares and prepared the clearings for improved grazing. Livestock grazing is confined to this improved pasture that is fenced into seven individual fields. The Blackfoot Grazing Association has a disposition with Alberta Environmental Protection to provide grazing for livestock.

Issues- The major vegetation issues identified in the preparation of the management plan were weed control, fire management, grazing management, and the protection of sensitive plant species.

Management Intent- Vegetation in the Blackfoot Recreation Area will be managed to maintain a diverse pattern of vegetation types, and to protect sensitive and rare native plant species and communities.

Forage resources will be managed on a long term, sustained yield basis. Other resource and recreation activities may be integrated within pasture areas, so long as there is minimal negative impact on grazing management

\subsubsection{Guidelines for Vegetation and Grazing Management}

The following specific guidelines will direct vegetation management.

Inventory and Monitoring- A vegetation study will be conducted to identify plant species considered "significant" for the area. Significant plants will be considered species that are provincially rare or threatened. Significant species may also include habitat that is uncommon in the region, and species that are outside their normal range.

A vegetation inventory will be undertaken to identify locations of significant plants within the Blackfoot. Identified locations and species would be red-flagged for protection from new developments and disturbances. Locations of rare or threatened species will be monitored to assess the long term condition of the sites and plants. 
Fire Management- All unplanned or wild fires will be controlled.

Prescribed burning or controlled burns may be used as a tool for grazing, vegetation and wildlife management. All prescribed fires will require preparation of a detailed prescribed burn plan, including the opportunity for public review and comment.

Fire management in the Blackfoot will be coordinated with Elk Island National Park to ensure mutual achievement of vegetation management objectives.

Insect and Disease Control- Insects or diseases that have a major impact on vegetation within the Blackfoot will generally not be controlled. Natural processes will be allowed to run their course. However, management action may be taken where insect or disease problems could affect pasture areas within the Blackfoot, or have significant adverse affects on surrounding lands.

Vegetation Rehabilitation- Rehabilitation of natural sites disturbed by construction or recreational activities will generally be undertaken with species that are native to the area, or vegetation species that will allow natural succession. Detailed rehabilitation seed mixtures are provided in Appendix I.

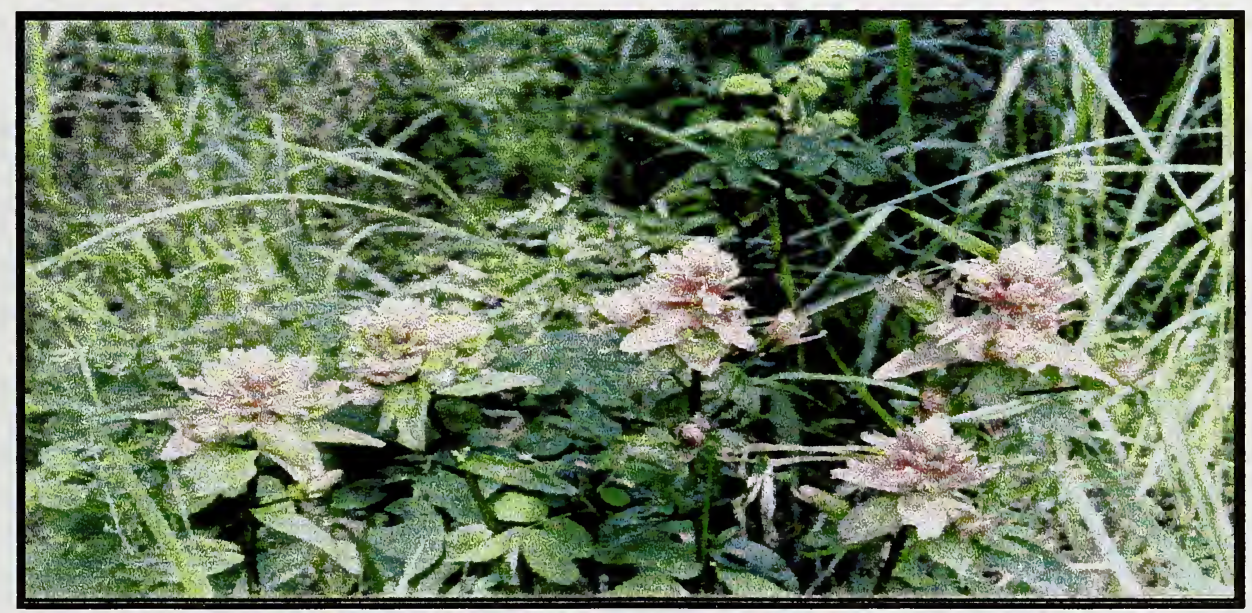

\section{Indian Paintbrush}

Weed Control- Weed control in Blackfoot will be conducted as required under the Provincial Weed Act. Weed control is necessary as a preventative measure to stop spreading of weeds to adjacent lands. The focus of control programs will be on restricted and noxious weeds, as defined in the Weed Act.

A coordinated control program among responsible agencies (Environmental Protection, Energy sector, Grazing Association, Municipalities, Elk Island National Parks) will be implemented in order to improve effectiveness, efficiency and reduce costs. 
The use of herbicides for weed control in the Blackfoot will be limited to localized sites and target the specific noxious or restricted weeds. All herbicides will be utilized in conformity with the recommendations of Alberta Agriculture (Blue Book).

Grazing Management - Forage resources within the fenced pasture areas will be managed on a long term, sustained yield basis. An allowance will be made for grazing carry-over of $40 \%$ of forage to meet wildlife needs.

Recreation activities will generally be allowed within pasture areas when the fields are not occupied by livestock, and there is minimal negative impact on the forage resources.

A grazing disposition with the Blackfoot Grazing Association will be maintained. Public Lands staff of Alberta Agriculture will be asked to continue to provide advisory services to Environmental Protection and the Grazing Association, for grazing management.

The number of grazing animals (animal unit months) will be balanced with forage supply. The number of animal units that can safely graze a given pasture is not a constant value and must be monitored through-out the season to adjust for site, weather conditions, plant condition, and grazing patterns. Alberta Environmental Protection and the Grazing Association, with the advise of Public Lands, will monitor conditions during the season and adjust grazing intensity to balance forage supply.

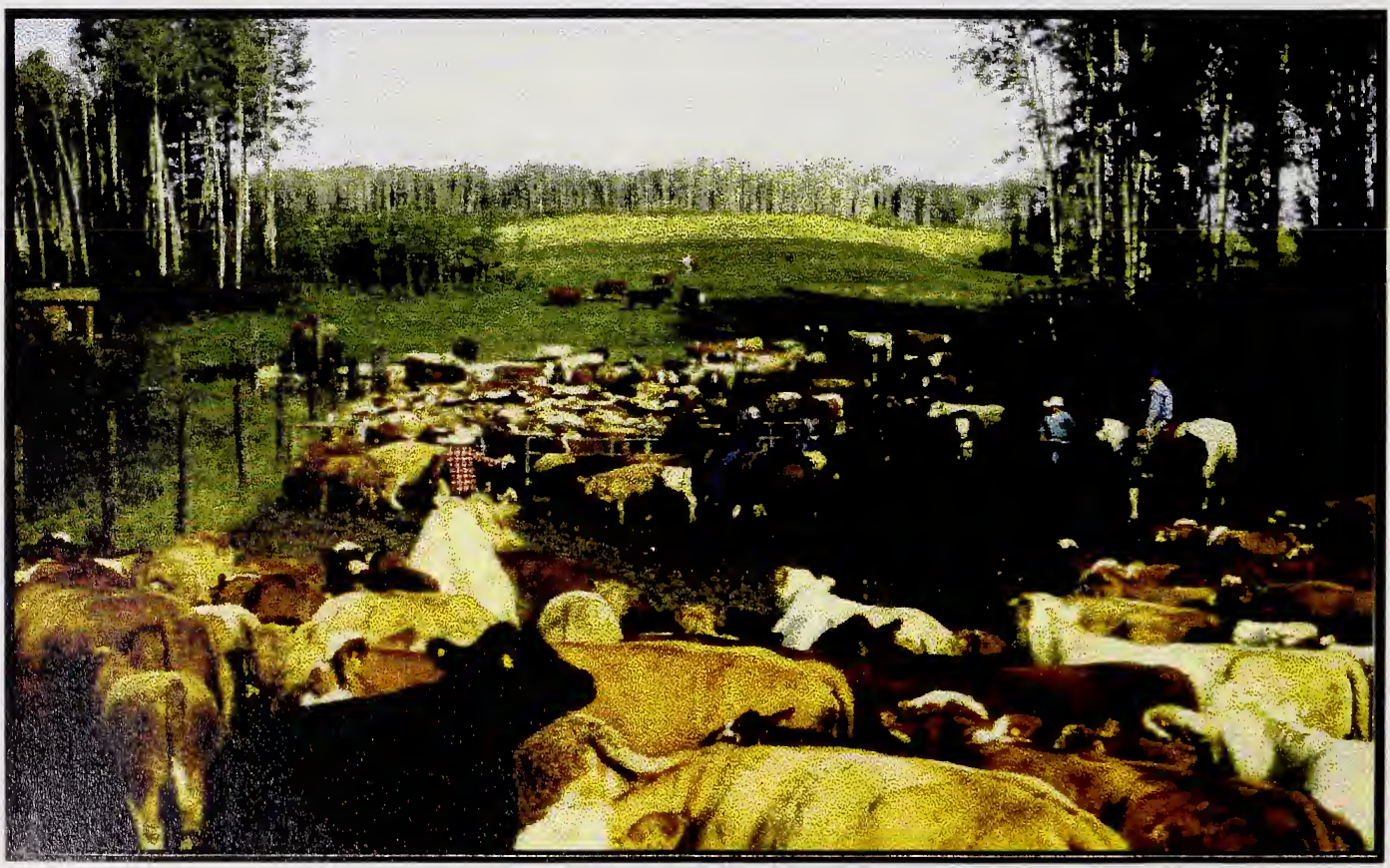

Blackfoot Grazing Association's Cattle at Elk Push Corner/Gray Alley 
A deferred-rotation grazing system will be utilized, commencing in approximately mid-May and ending mid-October. Actual starting and ending dates will vary each year depending on weather and forage conditions.

Grazing animals will be distributed over the pasture to ensure uniform livestock distribution and forage utilization. Tools such as alternative watering locations, salt placement, riding and crossfencing may be used.

Land areas managed for grazing will be maintained with desirable forage plants by the Grazing Association. Management techniques such as working- up pastures, seeding, spraying, fertilizing, rodent control, controlling brush encroachment, and developing stock watering locations may be considered. Fertilizers and pesticides will not be applied in buffer areas (30 metres) surrounding wetlands and water bodies.

Range conditions of the pasture will be monitored by the Grazing Association, in cooperation with Environmental Protection and the advise of Public Lands.

A site within the Recreation Area for a seasonal trailer or other temporary accommodation unit will be accommodated for Grazing Association staff. Placement of the accommodation unit will be subject to site specific location approval.

\subsection{Water and Wetland Management}

The Blackfoot Area has a highly variable local topography of undulating to strongly rolling hills. Drainage is primarily on a local scale into depressions between hills. Consequently, there are numerous small water bodies and wetlands found within the Area. Norris Creek that drains to the north from Blackfoot Lake is the only major watercourse that drains from the Recreation Area. Blackfoot Lake and Islet Lake are the two largest water bodies located within the Blackfoot.

An operational definition of wetlands is included here to clarify what type of features are being addressed in the management guidelines. Wetlands are permanently or intermittently wet land, shallow water or land-water margins, where water is present for a long enough period to support wetland or aquatic processes. Wetlands do not include flooded areas of shallow, open water on low relatively flat terrain that periodically forms as a result of snow melt or heavy rains.

Within the pasture areas of Blackfoot, the areas considered to be wetlands are those included in the treed areas that were not cleared in the original pasture development (see Map 1).

Issues- The primary issues related to water management are flooding along Norris Creek for lands downstream from the Blackfoot, the flooding of roads and facilities by beaver activities, the impact of removing beaver dams on water quality, the protection of aquatic vegetation and wildlife habitat, and the maintenance of livestock watering locations while protecting aquatic sites 
Management Intent- The emphasis for water management in Blackfoot will be on protection of water quality and maintaining a diversity of wildlife habitats and plant species, while accommodating resource and recreation activities. Access to good quality water for livestock will also be a requirement.

Water management action will be through coordinated and cooperative partnerships with surrounding landowners and agencies.

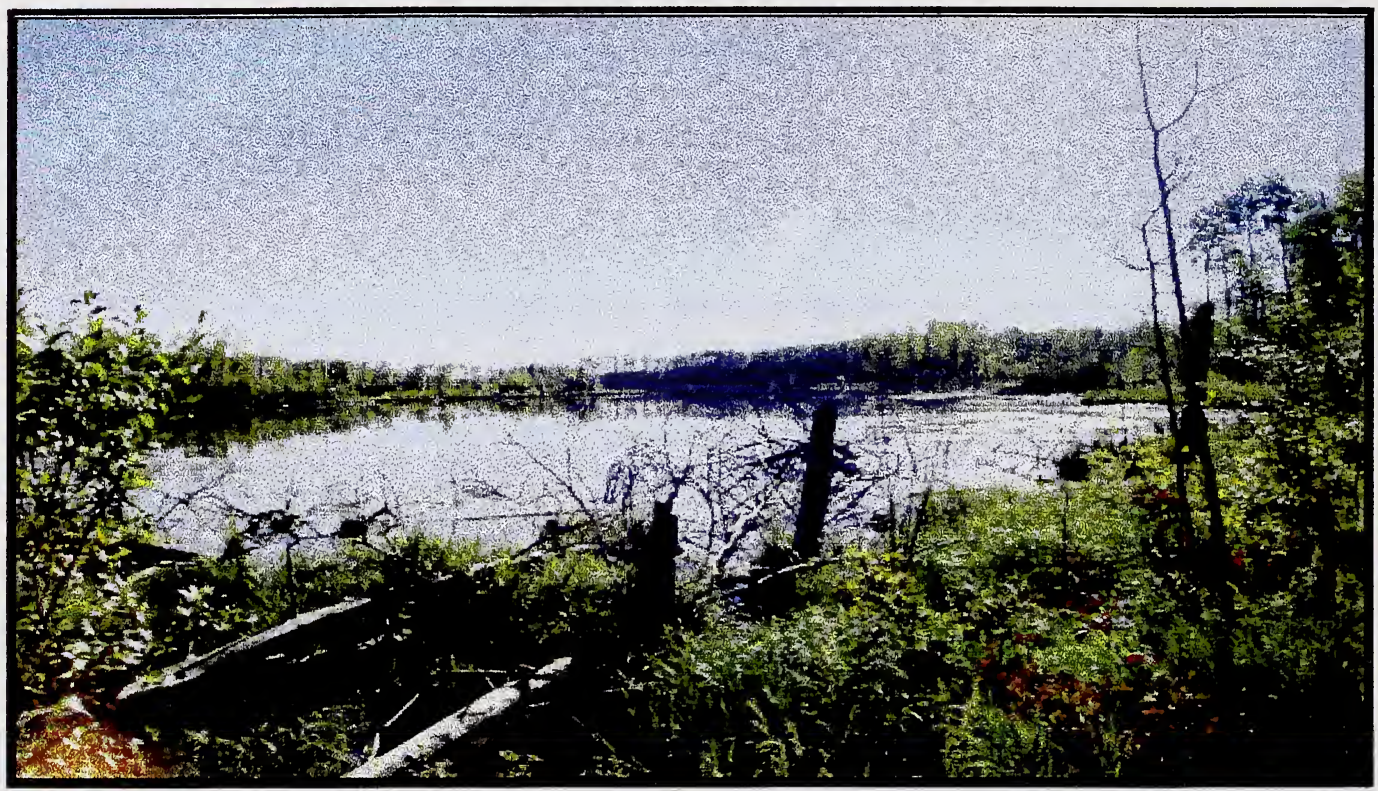

East Sawmill Lake

\subsubsection{Guidelines for Water and Wetland Management}

The following are specific water management guidelines.

Norris Creek Flooding- A coordinated water management strategy will be prepared to address flood prevention and protection for Norris Creek. The strategy will be prepared with participation of Elk Island National Park, the Counties of Beaver, Lamont, and Strathcona, downstream landowners, and Environmental Protection- Natural Resources Service.

Livestock Impacts on Water bodies- Action will be taken to reduce the impact of livestock watering on water bodies and wetlands through the use of protection techniques like cattle ramps to water bodies, and provision of remote water sources. Protection methods may be implemented through a partnership of relevant agencies including Alberta Environmental Protection, Alberta Agriculture, the Grazing Association, and Ducks Unlimited. 
Buffer Areas- Fertilizers and pesticides will not be spread in buffer areas (30 metres) surrounding wetlands and water bodies.

Beaver Control- Controlling of beavers will continue where their activities result in negative impacts on roads or recreational facilities. A range of management actions will be used including: ongoing winter trapping; installation of wire culvert cages; and reconstruction, relocation, or temporary closure of facilities to accommodate flooding. Removal of beavers and dams may occur when other management actions have failed or are considered impractical. The timing of dam removal will consider the downstream impacts on water quality and quantity, and the impact on facilities.

New Construction- New or realignment of existing roads, trails and pipelines will be located to avoid water bodies and wetland areas.

\subsection{Integration of Energy Industry}

There are numerous energy related facilities located within the Blackfoot, including 9 producing natural gas wells, over $16 \mathrm{kms}$ of pipeline, $25 \mathrm{kms}$ of access roads, and one compressor station. Many of these facilities existed prior to designation of the site as a Provincial Recreation Area.

Sub-surface mineral rights are leased for the entire Recreation Area, and additional exploration and drilling activity can be anticipated.

Issues- Issues related to energy developments within the Blackfoot were raised during the planning process. The major comments focused on concern about controls on how energy sites are operated and maintained, the location of new developments, the impact of energy facilities on recreation activities, grazing management and natural resources.

Management Intent- New energy developments and existing operations will be managed to minimize impacts on the natural resources of the Blackfoot. Energy activities will be integrated with other resource and recreation uses to minimize potential conflicts among the various parties.

\subsubsection{Guidelines for Energy Industry Integration}

The following statements will guide integration of energy resource development.

Seismic activity- Seismic exploration activities will be permitted so long as low impact techniques are employed (avoidance cutting, portable units, use of existing clearing and trails), and conflicts with other activities are avoided. 


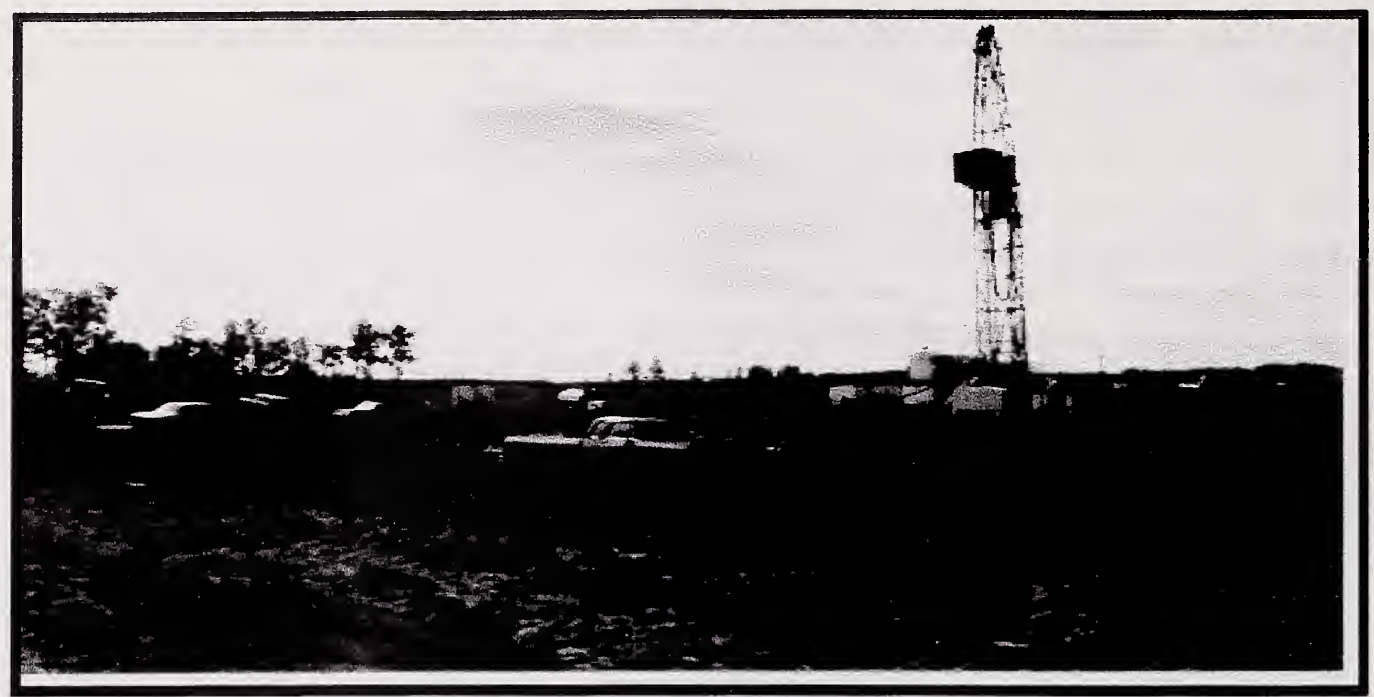

Exploration for Natural Gas

New Energy Developments- A collaborative approach to locating new energy developments will be used that allows siting of the development based on individual merit and constraints of the proposed area. Environmental Protection- Natural Resources Service will coordinate review of new energy developments, as well as represent recreational and environmental interests. The Grazing Association, and other parties as may be relevant, will participate in the review at the initiation stage to allow input to the location decision.

In the event of a disagreement relating to location of a new energy development, the parties involved will select a neutral party to arbitrate a decision (e.g. Public Lands or Energy Utilities Board).

Timing Restrictions on Drilling- Drilling will be permitted at any time of the year, subject to restrictions that will avoid specific conflicts with other activities (for example, grazing or special recreation events).

Drilling Wastes- Normal provincial regulations for disposal of drilling wastes will be applied by Environmental Protection within Blackfoot. Disposal may be done by one of several possible alternatives: I) on-site sumps, or ii) spraying of drilling wastes onto pasture areas or onto previously disturbed soils, based on site-specific conditions and the agreement of the Grazing Association (if applicable), or iii) hauling drilling wastes out of the Recreation Area.

Access To Energy Facilities- Access to energy facilities will be permitted by authorized personnel only (government and energy companies). Vehicular aceess will be restricted to access roads and used by all personnel (no short cuts). 
A road turn-around will be built outside the compressor station site located in the SW 16 T52 R20 W4M in order to avoid safety concerns relating to unauthorized vehicles entering the site.

Access Roads- Maintenance of the internal road system will be the responsibility of the energy companies. Road-use agreements will be required for any new users of the road system.

Vehicle access by the general public will continue to be restricted, except where authorized for a specific purpose or event. Damage to energy infrastructure (pipelines, roads) by recreation users will be the responsibility of the recreation group or the provincial government.

Emergency Response Plan- A coordinated and cooperative emergency response plan for energy related emergencies, and other types of emergencies, will be prepared with the participation of all major Blackfoot agencies and groups.

\subsection{Special Events}

The location of the Blackfoot Recreation Area adjacent to the Edmonton Region, plus the proximity of numerous smaller communities, make it a logical choice for holding numerous special events. Several events are held within the Recreation Area each year including the Canadian Birkebeiner Ski Festival, equestrian endurance rides and poker rallies, snowmobile poker rallies and dog sled races.

Issues- The public identified concerns about holding major special events within the Blackfoot and the impact of such events on the natural resources, potential conflicts with other recreation and resource activities, and the amount of staff time that can be committed to support these events.

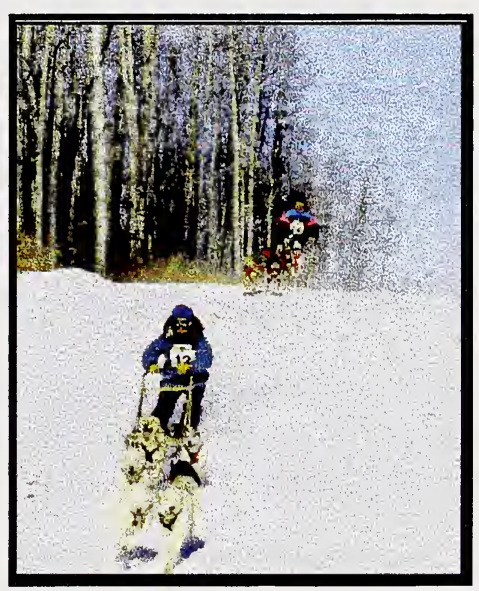

Dog Sled Races

Management Intent- Special events that focus on the natural attributes of the Blackfoot and are consistent with the Vision Statement and Objectives of the Area will be permitted. Special events will be considered that do not unduly restrict recreation opportunities of other users or impede ongoing resource activities. The events must not damage the natural or cultural resources of the Area, or place exceptional demands on the staff and budget resources of the Recreation Area.

\subsubsection{Guidelines for Special Events}

Permits- A Special Events permit will be required prior to the date of any event. At least thirty days notice will be required in order to allow arrangements to be made for staffing, and facility preparations. 
Trail Closures for Special Events- Temporary trail closures to accommodate special events will be considered in order to avoid conflicts with other users and to avoid any potential safety concerns.

Snowmobile Events- Snowmobile groups with special event permits from the County of Strathcona will be permitted to drive their snowmobiles directly into Waskehegan Staging Area for Special Events.

\subsection{Commercial Activities}

At present, there are no commercial services like food concessions or equipment rental services located within the Recreation Area.

Issues- Public comments during the planning process indicate a concern about the provision of commercial services within the Area.

Management Intent- Commercial services will not be considered within the Recreation Area. Commercial touring activities or instruction of outdoor activities may be considered, subject to Department policy requirements on qualifications, permits, and insurance.

\subsection{Regional Integration}

The Blackfoot Provincial Recreation Area is located in the County of Beaver, and adjacent to the Counties of Strathcona and Lamont. There are numerous residential acreages around the Area and three hamlets nearby, North Cooking Lake, Islet Lake and Antler Lake.

The Recreation Area is adjacent to Elk Island National Park and the Ukrainian Cultural Village. The Strathcona Wilderness Centre is located a few kilometres west of the Blackfoot. Beaverhill Lake is a major wildlife viewing location. Each of these sites attract visitors to the region for purposes that complement the role of the Blackfoot Recreation Area.

Issues- The benefits of working collectively with neighbours in the region was identified as an opportunity in the management planning process.

Management Intent- Blackfoot Provincial Recreation Area will work with its neighbours to advance the Vision and Objectives of the Area.

\subsubsection{Guidelines for Regional Integration}

The following statements will guide management for integration of the Recreation Area in the region. 
Integration Group- Blackfoot will contact the groups and agencies that surround the Recreation Area to explore the development of an ongoing mechanism to improve regional integration.

External Infrastructure- Issues regarding external infrastructure (road dust, noise, traffic) that were identified in the planning process will be forwarded to the relevant municipalities. Work to address the issues will be the responsibility of the local municipal authorities.

Issues relating to road upgrading and directional signs will be reviewed on a collaborative basis with the local municipalities. The group will approach Alberta Transportation and Utilities for cost sharing on any initiatives developed to address infrastructure concerns.

\subsection{Recreation Area Expansion}

Expansion of the Blackfoot is not a high priority at the present time. Consideration will be given to acquisition of adjacent lands if the expansion would improve the integrity of the Area, and is consistent with the Vision and Objectives for the site. Acquisition may be through different means including land transfers, donations, or purchase. Purchase of adjacent lands will be subject to budget availability, with opportunity for public discussion of the possible expansion.

Possible areas for expansion are lands on the east shore of Wanisan Lake and lands south of Islet Lake Staging Area. 



\subsection{PLAN IMPLEMENTATION}

Implementation of the Blackfoot Provincial Recreation Area Management Plan will be the primary responsibility of Alberta Environmental Protection- Natural Resources Service. Priorities for implementation will be set each year, as budget and resources are available. Appendix II includes a list of action requirements identified in the Plan. The list will be reviewed and updated as the Recreation Area's work plan is prepared each year.

Cooperation with partners and stakeholders will be extremely important to the successful implementation of the plan. Major partners include the Blackfoot Grazing Association, Pinnacle Resources Ltd. and Northwestern Utilities Ltd. and volunteer organizations like the Canadian Birkebeiner Ski Society, Alberta Trail Riders Association, and the Waskehegan Trail Association.

Coordination of implementation will rely on the cooperation and support of the many neighbours and municipalities surrounding the Recreation Area.

Cooperating Association- The formation of a formal cooperating association (i.e. Friends of the Blackfoot) will be initiated within twelve (12) months of the approval of the Management Plan. Membership could include major stakeholders and interested members of the public. The Association could provide ongoing support and input to Blackfoot management. A detailed terms of reference will be developed with the Association to identify specific roles and responsibilities.

Government Liaison Group- An ongoing government group to provide general coordination of the management of the Blackfoot Provincial Recreation Area will be formed. The liaison group would include representatives from Environmental Protection- Natural Resource Service, Public Lands and Elk Island National Park. Participation by other government departments (municipal, provincial and federal) may be desirable for particular management subjects.

\subsection{Plan Monitoring and Review}

Monitoring of the Management Plan will occur on an ongoing basis, and each year as the annual work plan for the Recreation Area is prepared and approved. Major unforseen changes in the operation of the Blackfoot may require review of the Management Plan. A formal review will occur no later than ten (10) years after approval of the Plan. Public involvement will be part of any formal review process for the Management Plan. 



\section{Appendix I \\ Vegetation Rehabilitation Seed Mixes}

\section{PASTURES}

Pastures HA, HB, HC, 1A, 2A, 3A, 5A, 5B, 6A, 6B, 6C, 6D, 7A

Carlton Brome

Creeping Red Fescue

Orchard Grass

Timothy

Meadow Brome

Alsike Clover

Meadow Foxtail

Pastures 1B, 1C, 2B

Carlton Brome

Creeping Red Fescue

Alsike Clover

Timothy

Yellow Sweet Clover

Pastures 3B, 3C, 4A, 4B, 7B
Alsike Clover
Carlton Brome
Creeping Red Fescue
Timothy
Orchard Grass
Yellow Sweet Clover

\begin{tabular}{ll}
$25 \%$ & \\
$20 \%$ & \\
$15 \%$ & \\
& $15 \%$ \\
$10 \%$ & \\
& $10 \%$ \\
\hline $5 \%$ & \\
\hline
\end{tabular}

$40 \%$

$20 \%$

$20 \%$

$15 \%$

$5 \%$

Perimeter Seed Mix

Alfalfa

Alsike Clover

Creeping Red Fescue

Crested Wheatgrass

Kentucky Bluegrass

Pubescent Wheatgrass

Yellow Sweet Clover
$20 \%$

$20 \%$

$20 \%$

$20 \%$

$10 \%$

$10 \%$ 


\section{WETLANDS}

$\underline{\text { Shrubs }}$

Salix spp.

Rosa acicularis

Forbs

Mentha arvensis

Scuterllaria galericulata

Epilobium angustifolium

Rumex acetosa

Graminoids

Calamagrostis canadensi

Juncus balticus

Carex atherodes (wet)

Carex rostrata (wet)

Suggested native seed mix

$20 \%$ Slough grass

$20 \%$ Fowl bluegrass

$20 \%$ Tufted hairgrass

$30 \%$ Reed canary grass

$10 \%$ Streambank wheatgrass

Marsh reedgrass *

Awned sedge *

* Currently not available

Note: Reed canary grass will probably out compete all other species.

Suggested tame mix (Previously disturbed sites only)

$10 \%$ Alsike clover

$10 \%$ Cicer milkvetch

$35 \%$ Reed canary grass

$10 \%$ Fowl bluegrass

$10 \%$ Streambank wheatgrass

$25 \%$ Meadow fescue
Common Name

Willow

$\%$ Cover

Prickly rose 20

2

Mint

Marsh skullcap

Fireweed

Dock

1

1

1

Marsh reedgrass

55

Baltic rush

10

Awned sedge

10

Beaked sedge

10 
FORESTED AREAS AND NATURAL GRASSLANDS (SANDY SOILS)

Trees

Populus tremuloides

Picea glauca

Populus balsamifera

$\underline{\text { Shrubs }}$

Alnus crispa

Spiraea betulifolia

Rosa acicularis

Salix spp.

Forbs

Cornus canadensis

Aralia nudicaulis

Apocynum androsaefolium

Epolobium angustifolium

Graminoids

Oryzopsis asperifolia

Bromus ciliatus

Agropyron trachycaulum

Elymus innovatus

Suggested native seed mix

$25 \%$ Hairy wildrye

$10 \%$ Sheeps fescue

$25 \%$ Slender wheatgrass

$20 \%$ Fringed brome

$20 \%$ Junegrass

Spiked trisetum?

* Currently not available

\section{Suggested tame mix}

$10 \%$ Alsike clover

$10 \%$ Cicer milkvetch

$10 \%$ Slender wheatgrass

$20 \%$ Creeping red fescue

$15 \%$ Smooth brome

$10 \%$ Perennial ryegrass?

$15 \%$ Hairy wildrye ?
Common name

Aspen

$\%$ Cover

White spruce

Balsam poplar

60

2

1

Green alder

35

White meadowsweet

14

Prickly rose

12

Willow

5

Bunchberry $\quad 30$

Wild sarsaparilla 26

Spreading dogbane $\quad 10$

Fireweed

1

Mountain ricegrass

25

Fringed brome

5

Slender wheatgrass

Hairy wildrye

2

10

Fireweed *

Peavine *

American vetch * 
FORESTED AREAS \& NATURAL GRASSLANDS (GRAY LUVISOLS, EUTRIC BRUNISOLS SOILS

Trees

Populus tremuloides

Populus balsamifera

Picea glauca

$\underline{\text { Shrubs }}$

Rosa acicularis

Alnus crispa

Shepherdia canadensis

Rubus ideaus

Viburnum edule

Forbs

Aralia nudicaulis

Epilobium angustifolium

Aster consipicuus

Cornus canadensis

Lathyrus ochroleucus

Linnaea borealis

Graminoids

Elymus innovatus

Calamagrostis canadensis

Schizachne purpurascens

Bromus ciliatus

Suggested native seed mix

$30 \%$ Hairy wildrye

$25 \%$ Fringed brome

$30 \%$ Slender wheatgrass

15\% Rocky Mtn. fescue

Marsh reedgrass *

Mountain ricegrass * (dry)

* Currently not available
Common name

Aspen

\%Cover

Balsam poplar

65

White spruce

3

2

Prickly rose

Green alder

6

Buffaloberry

6

Raspberry

5

Low bush cranberry

5

Wild sarsaparilla

9

Fireweed

9

Showy aster

9

Bunchberry

6

Peavine

6

Twinflower

6

Hairy wildrye

Marsh reedgrass

Purple oatgrass

3

Fringed brome

1
Peavine *

American vetch *

Fireweed *

Suggested tame mix

$15 \%$ Oxley Cicer milkvetch 'noducoat'

$15 \%$ Alsike clover 'Noducoat'

$20 \%$ Orchardgrass (Kay)

$25 \%$ Meadow fescue or Creeping red fescue, or Smooth brome

$10 \%$ Meadow foxtail or Reed canary grass (Moist sites)

$15 \%$ Smooth brome 


\section{Appendix II \\ Action Requirements}

The following is a list that summarizes the tasks necessary to implement the Blackfoot Recreation Area Management Plan (as of April 1997). The list is presented as the topics are outlined in the Plan. The priority for completing each task, and responsibility for action, will be reviewed as the annual work plan for the Blackfoot is prepared. Input on priorities will be discussed with the Government Liaison Group and the Cooperating Association.

\section{Recreation Management}

- expand trail etiquette and safety information.

- develop partnerships for construction of equestrian trails around Field 7.

- monitor trail conditions, and upgrade wet portions.

- develop partnerships for trail work.

- implement mountain bike trail connection to Blackfoot Staging Area.

- initiate south east perimeter dog sledding trail, monitor wildlife impact.

- initiate snowmobile trail grooming in open Fields.

- brush snowmobile connection from Central Staging Area.

- extend time of trail sharing for Birkebeiner route

- accommodate trail connections to surrounding trails on trial basis.

- redesign/expand Blackfoot Staging Area parking lot.

- bridge revisions to accommodate horses with wagons/sleighs.

\section{Heritage Appreciation}

- adopt heritage appreciation themes.

- investigate development of an Interpretive Centre through partnerships.

- recognize historical significance of existing trails and sites.

- initiate coordination of heritage appreciation services with neighbours.

\section{Wildlife Management}

- prepare inventories for selected indicator species, and primary hunting and trapping species.

- initiate overlap of white-tailed deer and elk hunting seasons.

- investigate a system to make Discharge Permits more available to hunters.

- adopt new population goals for ungulate species.

- upgrade and maintain ungulate fence.

- expand opportunities for wildlife viewing. 


\section{Vegetation and Grazing Management}

- identify significant plant species for the Area, undertake an inventory of significant plants.

- implement rehabilitation projects using identified seed mixtures.

- initiate a coordinated weed control program.

- formally request advisory service of Public Lands staff for grazing management.

- monitor range conditions to adjust grazing intensities.

\section{Water and Wetland Management}

-. initiate preparation of a coordinated water management strategy for Norris Creek.

- develop partnerships to reduce impacts of livestock on water bodies and wetlands.

\section{Integration of Energy Industry}

- implement a new collaborative approach to locating new energy developments.

- apply new options for disposal of drilling wastes.

- coordinate construction of road turn-around at compressor site.

- prepare a coordinated emergency response plan.

\section{Regional Integration}

- explore mechanisms to improve regional integration.

- identify external infrastructure issues to relevant municipalities.

\section{Recreation Area Expansion}

- identify land acquisition priories to relevant agencies.

\section{Plan Implementation}

- initiate formation of a cooperating association.

- initiate formation of an ongoing government liaison group. 

National Library of Canada

Bibliothèque nationale du Canada

33286513492088 